\title{
Una Roma in cui giocare: ricostruzioni 3D e serious games dalla pianta del Nolli
}

\author{
Tommaso Empler \\ Adriana Caldarone \\ Elena D'Angelo
}

Abstract

Il contributo proposto vuole esporre l'esperienza condotta durante la ricostruzione di Roma alla metà del '700, nell'intento di dar vita a serious games in grado di comunicare e divulgare un contesto espressivo delle vicende sociali e culturali della città dell'epoca. L'approccio educativo scelto impone un'attenta analisi dei dati e delle fonti, per cogliere, tradurre e sintetizzare gli elementi storici rilevanti. II punto di partenza della ricostruzione è la lettura del luogo, così da affidare alla rappresentazione un ruolo fondamentale e creare un legame imprescindibile con l'ambientazione che sia il più possibile fedele alla realtà. II percorso di ricostruzione si sviluppa secondo fasi precise, ognuna delle quali riveste un ruolo fondamentale: dalla definizione dell'orografia si passa alla costruzione della base cartografica, si compone la scena urbana con isolati, strade, vicoli e piazze, si identificano gli elementi primari, secondari e terziari, fino all'editing e al completamento della narrazione. La digitalizzazione dei modelli viene attuata tramite diverse procedure, grazie alle quali si compie un processo di discretizzazione e perfezionamento delle informazioni. L'obiettivo dei serious games è di proiettare i giocatori nella storia, coinvolgerli nelle dinamiche e nelle ambientazioni di un tempo passato utilizzando lo strumento come supporto alle forme tradizionali di insegnamento nelle scuole per offrire contenuti didattici avvincenti di alta qualità.

Parole chiave

serious games, affidabilità, Nolli, linguaggi.

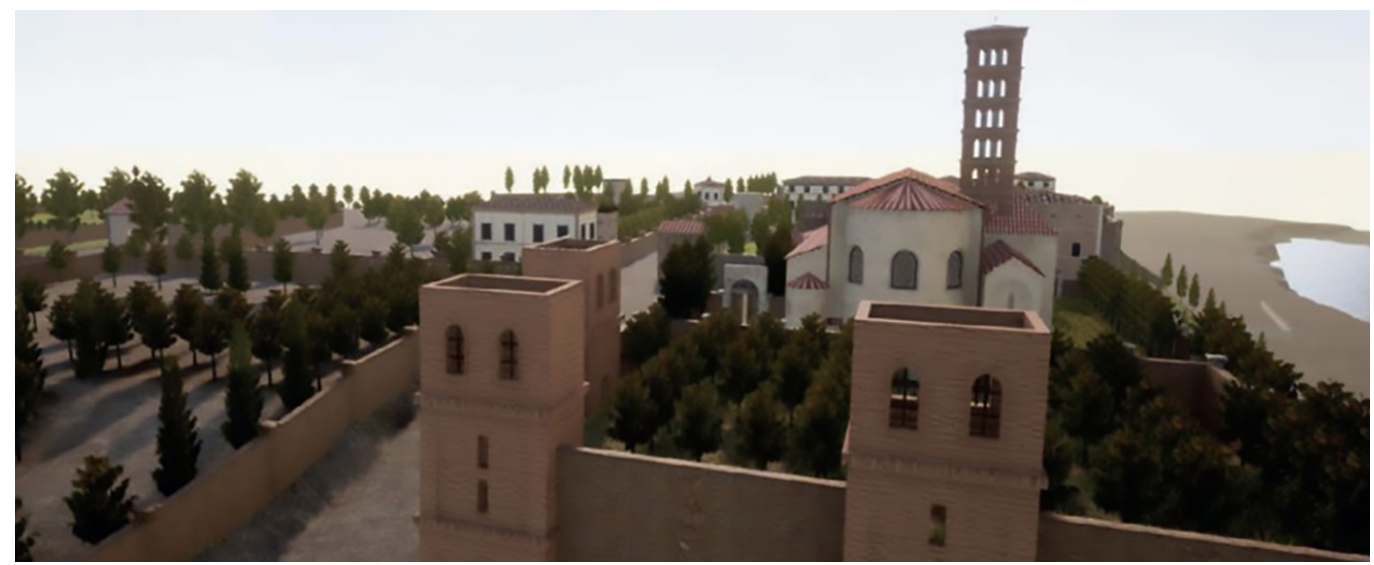




\section{Introduzione}

L'ampia diffusione del fenomeno culturale dei videogiochi impone delle riflessioni sia nel mondo della pedagogia (sul ruolo che essi assumono nell'educazione), sia nel settore disciplinare del disegno, sul ruolo dei linguaggi comunicativi che essi adoperano per le rappresentazioni visuali. I due mondi e concetti sono implicitamente collegati tra loro.

Le modalità di apprendimento sono classificabili in due diverse classi: simbolico-ricostruttivo, che permette di imparare a decodificare simboli ricostruendone nella mente il significato (ad esempio lettura e interpretazione), percettivo-motorio, nel quale un individuo percepisce il contesto che lo circonda e interagisce con esso attraverso delle azioni in un continuo scambio. I videogiochi ammettono di esercitare le due modalità contemporaneamente, anche in modi non consentiti nella realtà [Antinucci 20 14], aumentando le capacità cognitive. Su questi presupposti si basano i serious games, i quali, secondo alcuni opinionisti, servono a imparare divertendosi, ma, soprattutto, vivendo esperienze in prima persona dentro "la storia, la geografia, la matematica o l'architettura". È uno strumento che può essere utilizzato integrato e affiancato alle forme tradizionali di insegnamento delle materie nelle scuole di ogni ordine e grado, superando il concetto del libro di testo, offrendo, allo stesso tempo, contenuti didattici coinvolgenti e modulabili in funzione delle conoscenze di ciascun allievo. Possono anche essere proposte ludiche rivolte a un pubblico più ampio e viste alla stregua dei più diffusi giochi commerciali, in cui il player si muove in un contesto dove le informazioni trasmesse sono veritiere e costruite su basi scientifiche.

Affinché le esperienze siano vissute come 'reali', due elementi assumono un ruolo fondamentale: le rappresentazioni visive degli scenari in cui il giocatore si muove ed esplora; l'interazione, secondo cui a ogni input percettivo corrisponde una risposta dell'utente.

Si aggiunge agli elementi finora descritti, l'uso della narrazione come strategia comunicativa per il veicolo di contenuti. L'importanza cognitiva dello storytelling è nota sin da tempo, in quanto il racconto, grazie alla variabile emozionale, genera processi ermeneutico-interpretativi, aumenta il coinvolgimento e la capacità di introiettare significati strutturati e favorisce lo spirito critico grazie alla ricerca di risoluzioni di problemi [Viola, Idone Cassone 20 17]. I serious games adoperano una modalità di racconto che fa uso di immagini come mezzo espressivo, meglio nota come Visual Storytelling.

Nei percorsi educativi e di apprendimento, ai serious games può anche essere associato un percorso di gamification visto come l'utilizzo di elementi mutuati dai giochi e delle tecniche di game design, in contesti esterni.

Fig. I. Un'immagine di Assassin's creed e la ricostruzione tridimensionale del Pantheon con un falso storico. Immagine da $<$ https://areyouserious attervista / a reyouserious.aled ed-puo-essere-conside(consultato 25 maggo (consultato il 25 maggio 2021)

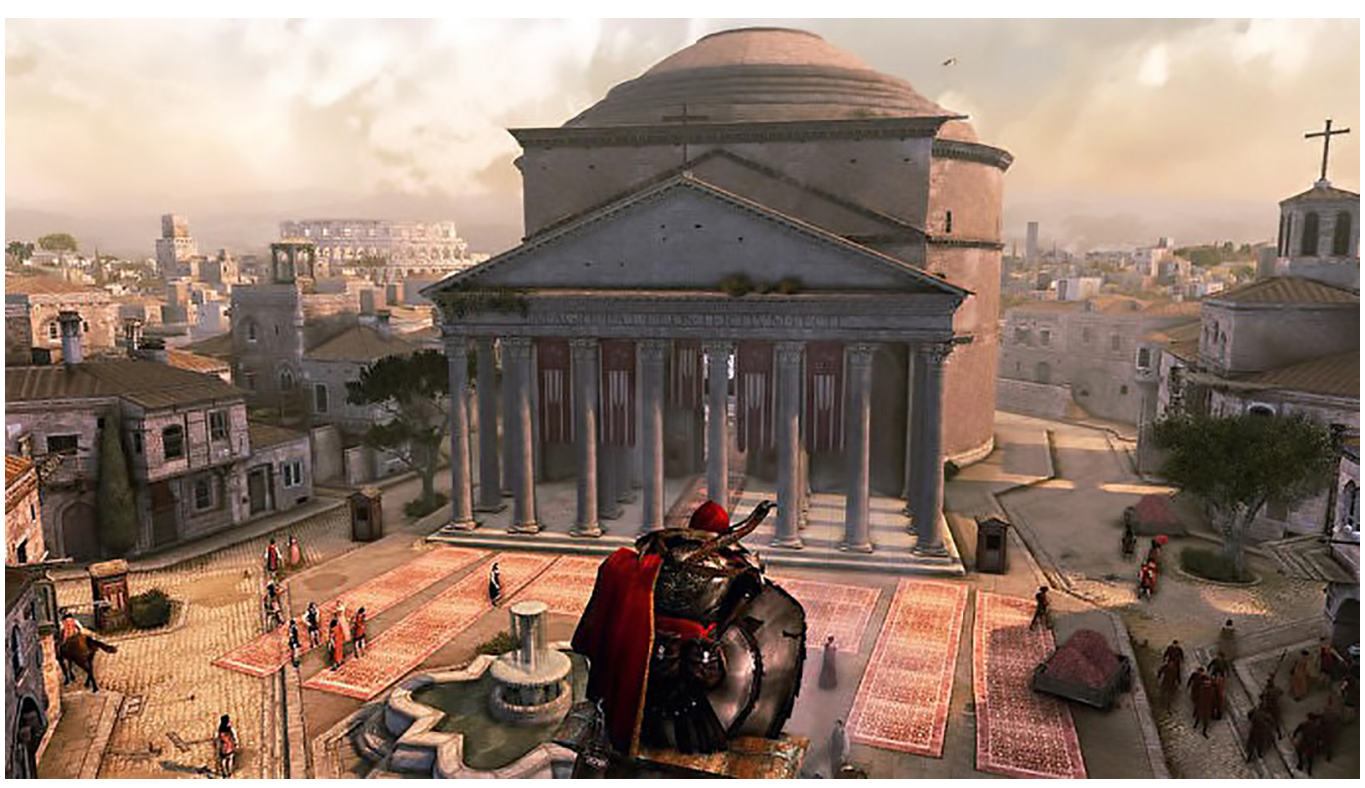


Fig. 2. Un capitolo del gioco del rione Trevi incentrato sulla famiglia Barberini. Lo scopo de gioco è ricomporre lo stemma nobiliare scoprendo aneddoti sui rapporti tra Roma ed alcuni personaggi emblematici della famiglia.

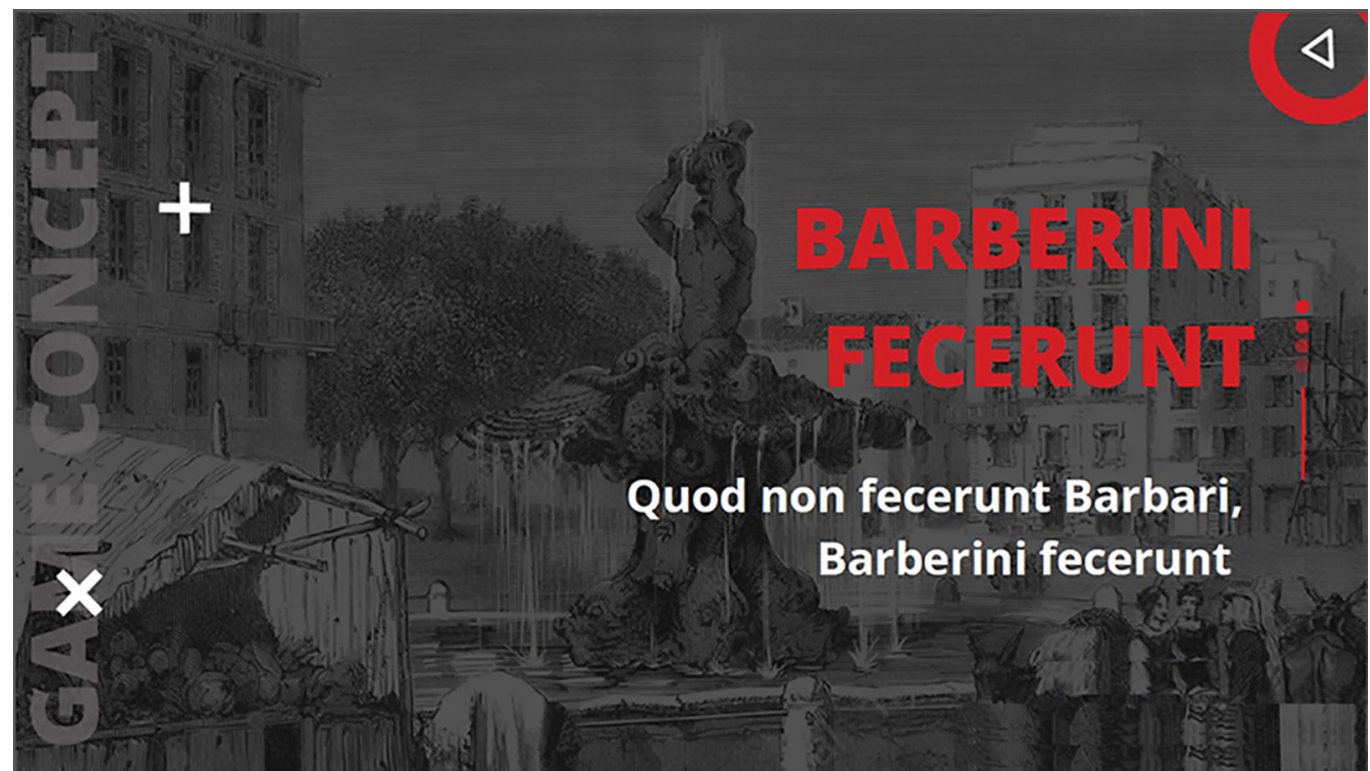

Questo è il motivo per cui la gamification interviene in situazioni in cui coinvolgere un pubblico è più difficile rispetto ad altre. I videogiochi coadiuvano i musei a comunicare in modo semplice e innovativo, ma soprattutto possono rendere il visitatore attivo, ossia parte integrante dell'esperienza che sta vivendo.

I settori di ricerca implicati in un percorso legato ai serious games sono molteplici e riguardano in via preliminare la redazione di un documento di progettazione denominato Game

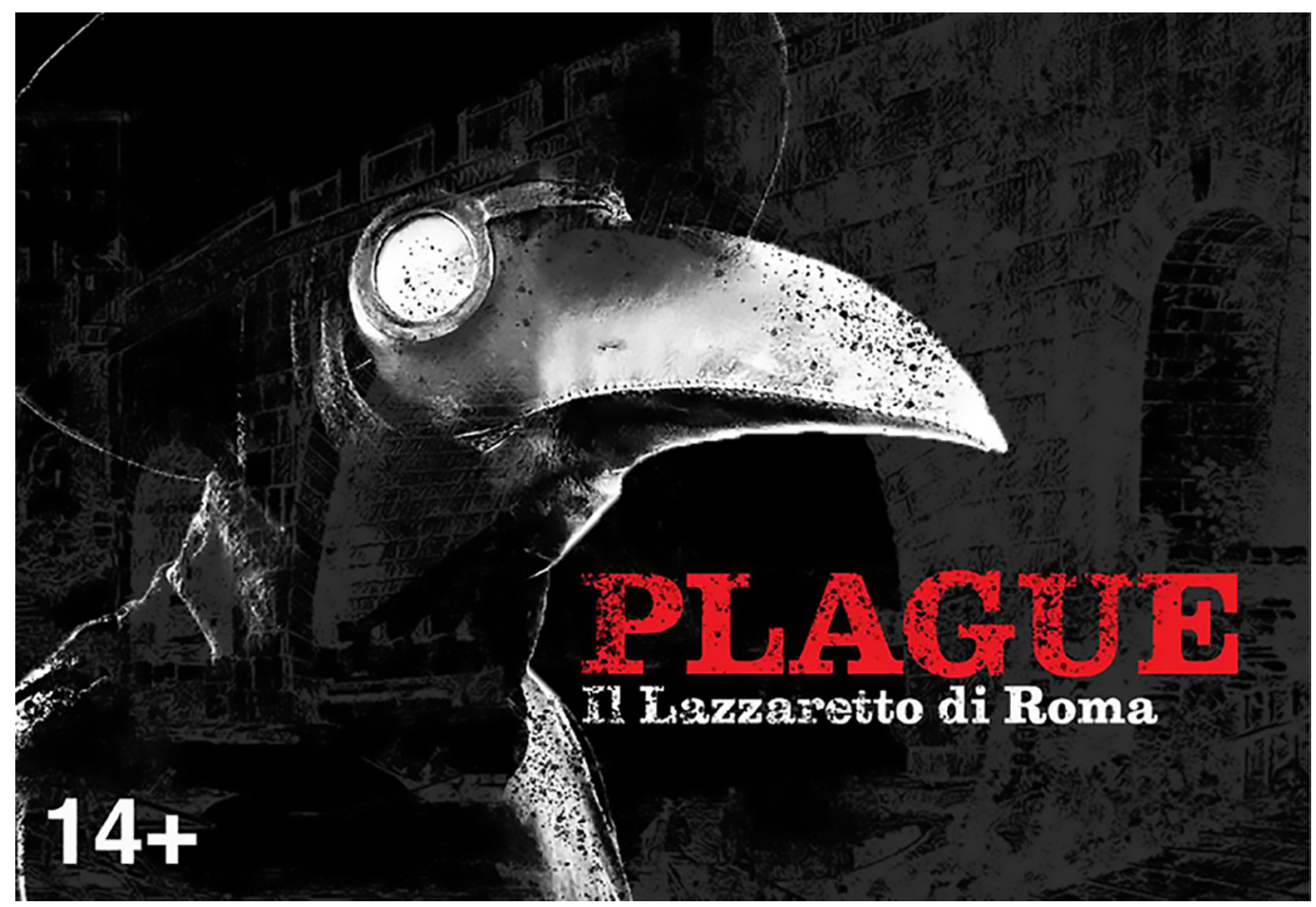

Fig. 3. Un capitolo del gioco del rione Ripa, ne quale il giocatore deve aiutare un personaggio ritrovare la sua famiglia tra isola tiberina e ghetto ebraico, dopo 'epidemia di peste che colpì Roma tra il '600 ed i) '700, risolvendo enigmi, percorsi e minigiochi. 
Fig. 4. Elementi primari: chiesa di Santa Maria in Traspontina in una incisione di Giovan Battista Falda (I) e modello tridimensionale (2); (3) chiesa di San Giacomo a piazza Scossacavalli (og piazza Sant'Andrea della Valle), in una incisione d Gale), in una incisione di Giuseppe Vasi e modello D tridimensionale, (4) palazzo dei Convertend in una incisione di Pietro Paolo Girelli e modello 3D (elaborazione digitale di G. D'Aniello, R. Favia).
Design Document (GDD), dove sono predisposti:

I. Gli obiettivi educativi;

2. Target di riferimento;

3. Gli effetti commerciali, psicologico-emozionali da indurre negli utenti;

4. Genere e numero di giocatori;

5. La storia e il filo narrativo (storytelling);

6. L'ambientazione;

7. Lo scenario (definizione del contesto e del problema da risolvere);

8. Gli obiettivi di gioco;

9. I personaggi;

10. II gameplay (meccanica di gioco);

| I. I| suono e la musica;

12. L'interfaccia utente e i comandi;

13. L'eventuale monetizzazione.

Ultima componente, ma non di minore importanza, è la redazione di uno storyboard: una rappresentazione grafica, sotto forma di sequenze disegnate, delle scene che in ordine cronologico, identificano eventualmente anche i diversi quadri e/o livelli di gioco.

Tutti gli elementi illustrati fanno parte di un sistema su cui è stato sviluppato il caso applicativo, ovvero la ricostruzione di Roma alla metà del '700, basata sulla pianta del Nolli del I748, in cui la disciplina della rappresentazione recita un ruolo primario e fondamentale legato all'ambientazione e alla affidabilità storico-geometrica della ricostruzione.

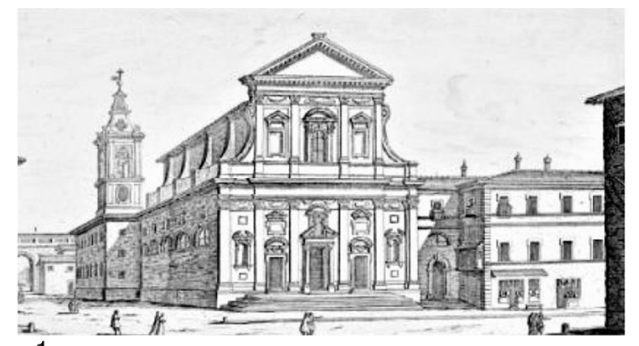

1
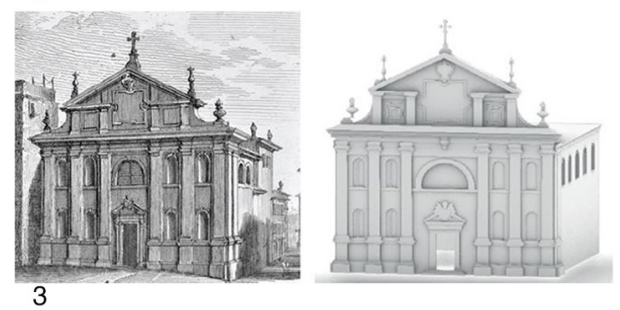

3

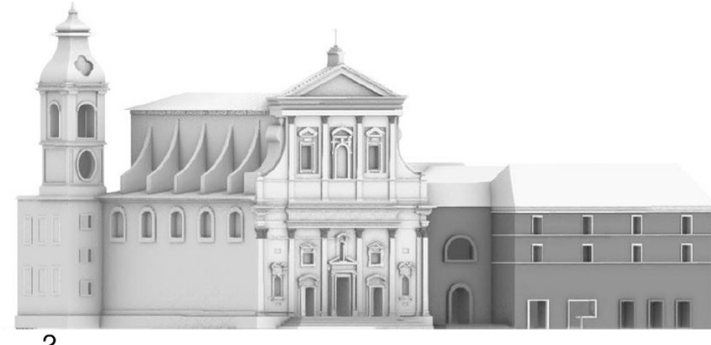

2
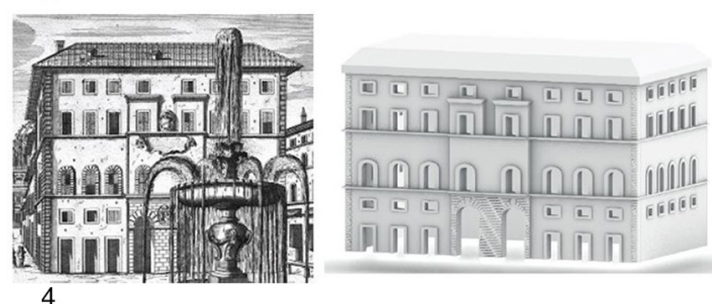

\section{Stato dell'arte}

La ricerca e le applicazioni nell'ambito dei serious games sono molteplici e realizzate in diversi settori che vanno dal campo della ricerca applicata, al campo della formazione, al settore dei video ludici commerciali.

Per quanto riguarda il settore della ricerca e dei beni culturali, si riportano l'esperienza condotte dal CNR in collaborazione con I'Università di Padova e finanziato dal MIUR e dalla Regione Veneto.

Tra le elaborazioni svolte dal CNR-ITABC risulta significativo il progetto Aquae Patavinae VR dall'acquisizione 3D al progetto di realtà virtuale: una proposta per il museo del termalismo. Si tratta di una ricostruzione virtuale di alcuni siti archeologici del paesaggio termale dei Colli Euganei, attualmente inaccessibili, fruibile tramite piattaforma real-time. II progetto affronta la ricostruzione del paesaggio archeologico mediante strumenti di archeologia virtuale 
open-source, rendendo espliciti i dati acquisiti e dunque comprensibili sia alla comunità scientifica che agli utenti esterni al settore.

Le applicazioni di serious games possono riguardare, inoltre, l'ambito della formazione. Un esempio è quello relativo alla formazione dei chirurghi in sala operatoria, con lo scopo di preparare i professionisti a situazioni quali complicazioni inaspettate. Così la fondazione Policlinico Universitario A. Gemelli ha ideato un serious game su alcune operazioni chirurgiche nel tentativo di ridurre i rischi dovuti agli imprevisti che potrebbero insorgere durante l'operazione reale.

La piattaforma XVR, invece, fornisce la possibilità di ricreare diversi scenari che presentano condizioni di pericolo (incendi, incidenti stradali o aerei, ecc.) consentendo all'utente di allenarsi per aumentare la propria esperienza nella gestione di potenziali situazioni di emergenza.

Sono diverse le aziende specializzate nella creazione di serious games volti alla formazione e che sfruttano ambienti virtuali per consentire lo sviluppo di capacità operative all'interno di contesti 'sicuri'.

La terza applicazione trova riscontro in giochi commerciali quali, ad esempio, Assassin's Creed Origins Discovery tour e Pacemaker. Il primo è un videogioco, sviluppato presso Ubisoft Montreal, che riproduce virtualmente storie fittizie ambientate in contesti open world, all'interno dei quali il giocatore viene a conoscenza della trama attraverso il susseguirsi degli eventi. II gioco ha ricevuto diverse critiche positive soprattutto per la tecnica narrativa, la grafica e la forte connessione storica con gli eventi narrati. Le ambientazioni raffigurate tentano, dunque, di ricreare il contesto realmente esistito attenendosi solo in parte alla struttura urbana del passato (fig. I).

Nel secondo caso il videogioco è sviluppato da ImpactGames. II gioco simula la situazione governativa entro cui si svolge il conflitto israelo-palestinese. Di fatto è concepito come un serious game per il carattere istruttivo che esprime, proponendo una risoluzione pacifica del conflitto che da decenni si sta consumando all'interno di questi territori. Inoltre, gli eventi tradotti nel contesto virtuale sono in parte realmente accaduti e raccontano lo sviluppo di una vicenda rilevante per la storia dell'umanità.

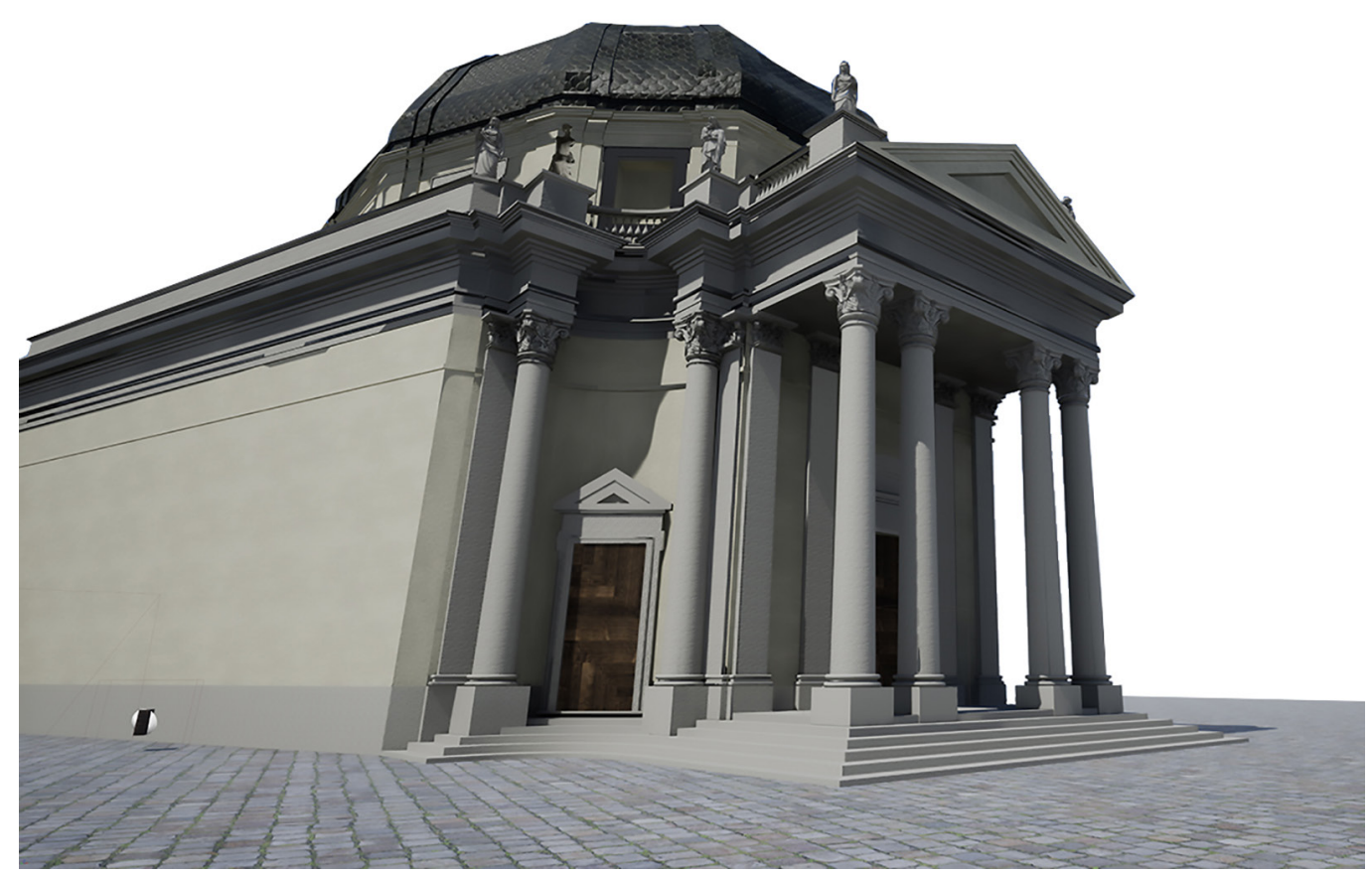


Fig. 6. Realizzazione di un edificio secondario (elaborazione digitale di F. G. D'intino, E. Kinj)

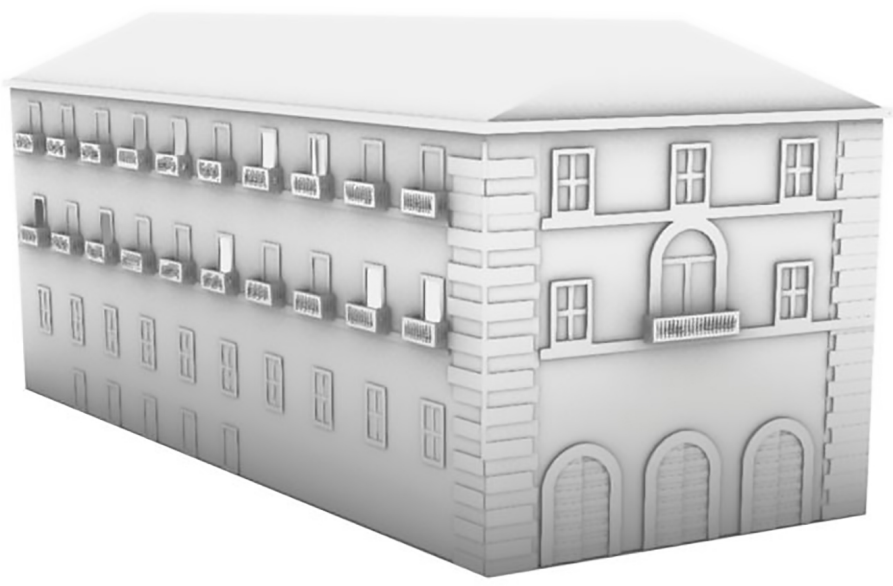

\section{Metodologia applicata}

Il processo seguito per comunicare e divulgare la ricostruzione di Roma alla metà del '700 secondo un approccio educativo ha coniugato la libera creatività narrativa (connessa a fatti o aneddoti storici realmente avvenuti) alla necessità di un rigore scientifico per quel che riguarda l'affidabilità della ricostruzione e delle informazioni. La parte di ricerca che viene approfondita in questa sede si incentra sugli aspetti legati all'ambientazione, dove si concentrano competenze trasversali legate alla rappresentazione (come la modellazione 3D), alla storia dell'architettura (storia dei luoghi e degli stili architettonici), al rilievo (registrazione di dati per ricostruzioni attendibili di oggetti e spazi appartenuti al passato). Gli spazi tridimensionali devono essere caratterizzati da una giusta proporzione tra gli oggetti che compongono la scena, un'affidabilità geometrica e storica degli elementi, e da una riconoscibilità dei luoghi navigabili.
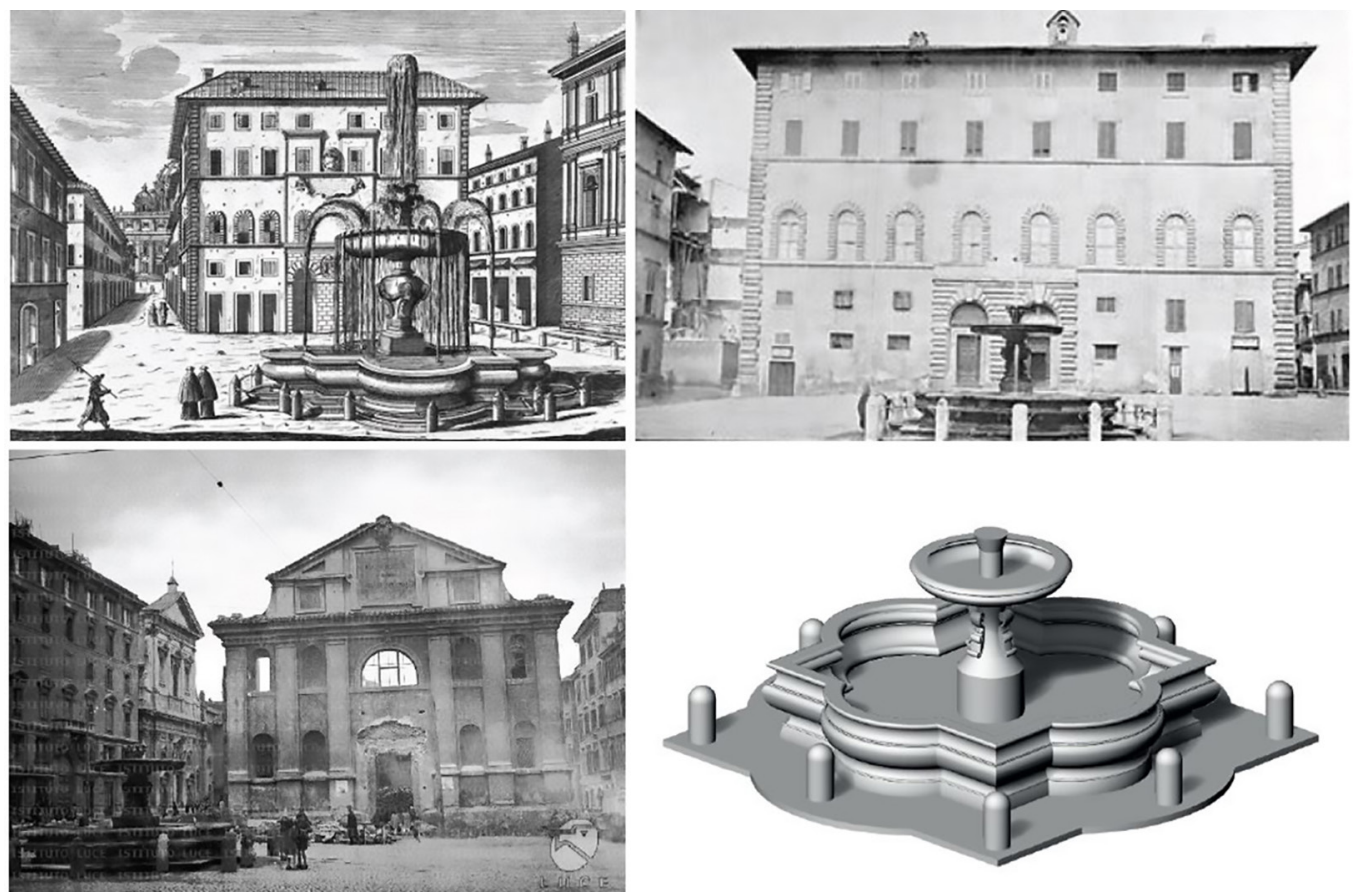

Fig. 7. Elemento terziario: Fontana in piazza Scossacavalli, incisioni, foto storiche e modello tridimensionale (elaborazione digitale di G. D'Aniello, R. Favia). 
Per quel che riguarda obiettivi di gioco e l'impostazione dello storytelling, si è deciso di dividere la città in rioni e costruire su ognuno una narrazione e un obiettivo indipendente, in una impostazione basata su più livelli di gioco (figg. 2, 3). In ogni capitolo sono stati stabiliti i main character (interpretati dal giocatore) e i personaggi non giocanti che assumono il ruolo di guida durante lo sviluppo della trama.

Nel videogioco ogni utente diviene il protagonista della storia e la influenza. A seconda delle scelte che si compiono il finale cambia. Questo metodo aiuta la connessione con la storia e facilita una migliore veicolazione dei messaggi.

La ricostruzione di Roma, basata sulla pianta di Roma del Nolli del 1748, presenta la lettura sovrapposta di informazioni derivanti da dati e fonti documentarie diretti e indiretti:

I. la pianta di Roma del Nolli del 1748;

2. le piante di Roma di Greuter del 1618, di Antonio Tempesta del 1645, di Giuseppe Vasi del I78I;

3. le vedute di Roma di Giuseppe Falda del I67I, di Giovan Battista Piranesi intorno al I750, di Giuseppe Vasi del 1754, di Luigi Rossini del 1822;
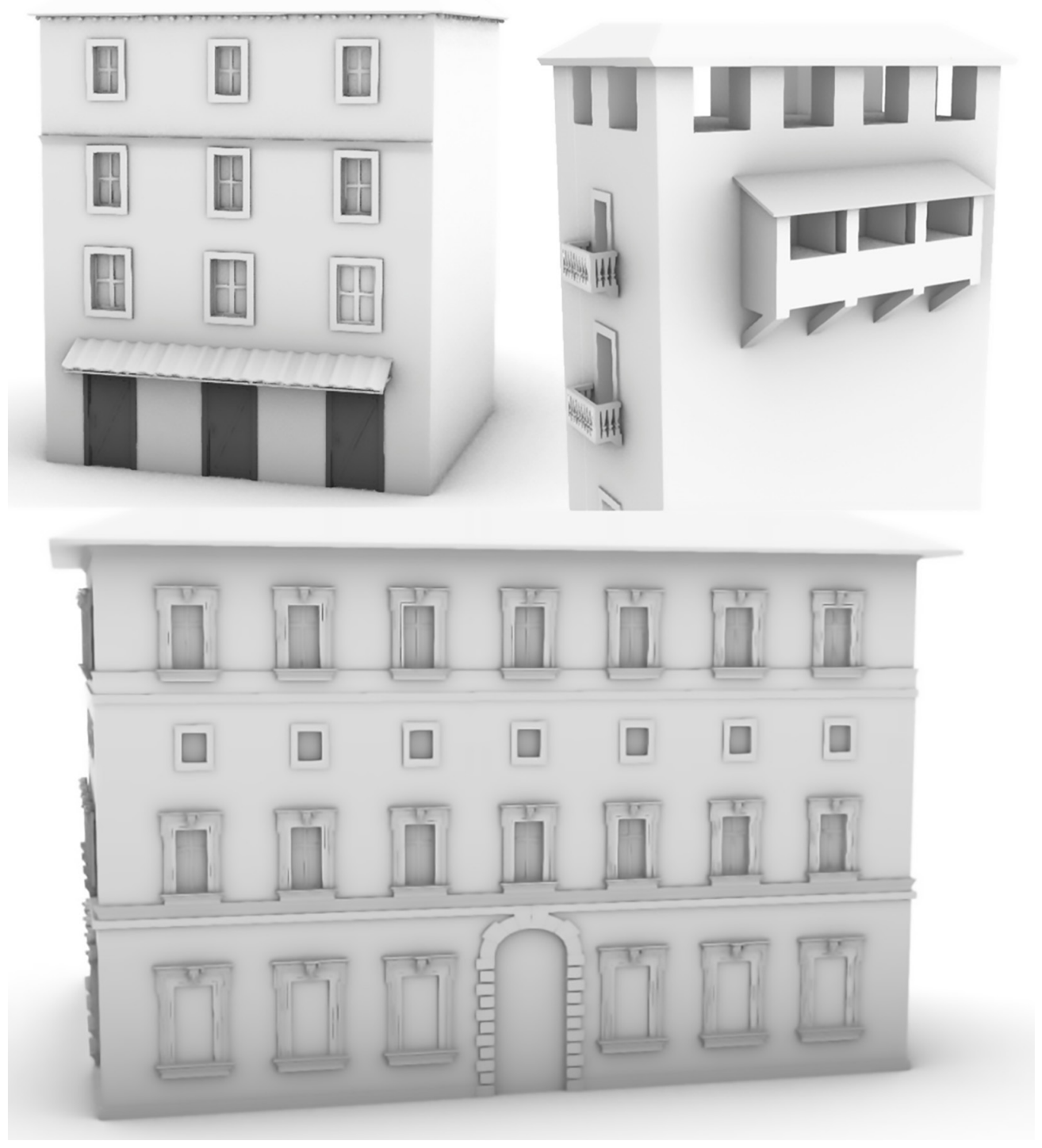
4. gli edifici e gli spazi ancora oggi visibili nella loro conformazione originaria, rilevabili a vista o con metodi strumentali (fotogrammetria o laser scanner terrestre).

II processo di ricostruzione prevede una organizzazione per tre fasi fondamentali e per ognuna di essa sono previsti:

I. ricerca storica e analisi dei dati;

2. individuazione e schematizzazione degli elementi storici e architettonici significativi;

3. modellazione tridimensionale e digitalizzazione tramite diversi strumenti software;

4. verifica ed editing.

Nella prima fase si ricostruisce l'orografia del terreno attraverso l'interpretazione di registri storici e mappe storiche.

Nella seconda fase si costruisce la base cartografica: si mette a punto l'articolato quadro della storia urbana di Roma dalla metà del '500 alla metà del '700, epoche di rinnovamenti e di notevole crescita urbana. I documenti cartografici, analizzati nei molteplici aspetti, comprendono lo studio delle piante storiche di Greuter, Tempesta, e Vasi, le quali vengono messe a confronto con la pianta di Roma del Nolli per comprendere il processo evolutivo della città.

Durante la terza fase si compone la scena urbana che sarà esplorata dall'utente. Si rappresenta dapprima la struttura di pieni e vuoti, assemblando via via l'impianto urbano che definisce quindi isolati, strade, vicoli e piazze.

Successivamente si identificano tre categorie di elementi costituenti la scena, distinti in primari, secondari e terziari. Gli elementi primari sono componenti architettonico-urbane emergenti all'interno del tessuto, come piazze principali, chiese e palazzi nobiliari, oggetti per lo più iconici e rappresentativi per la riconoscibilità dei luoghi. La rappresentazione è veritiera e con un alto livello di dettaglio (figg. 4,5). Elementi secondari sono quel complesso di edilizia minore (case, magazzini, laboratori) che compone percettivamente e visivamente la morfologia urbana, la cui tipologia architettonica è similare in tutto il tessuto cittadino e appartenente a una categoria simbolica di palazzo (fig. 6). Infine, gli elementi terziari sono oggetti, per lo più architettonico-decorativi, caratterizzanti la scena urbana, come fontane, obelischi, statue ed elementi artistici, che contribuiscono a delineare i connotati del centro cittadino (fig. 7).

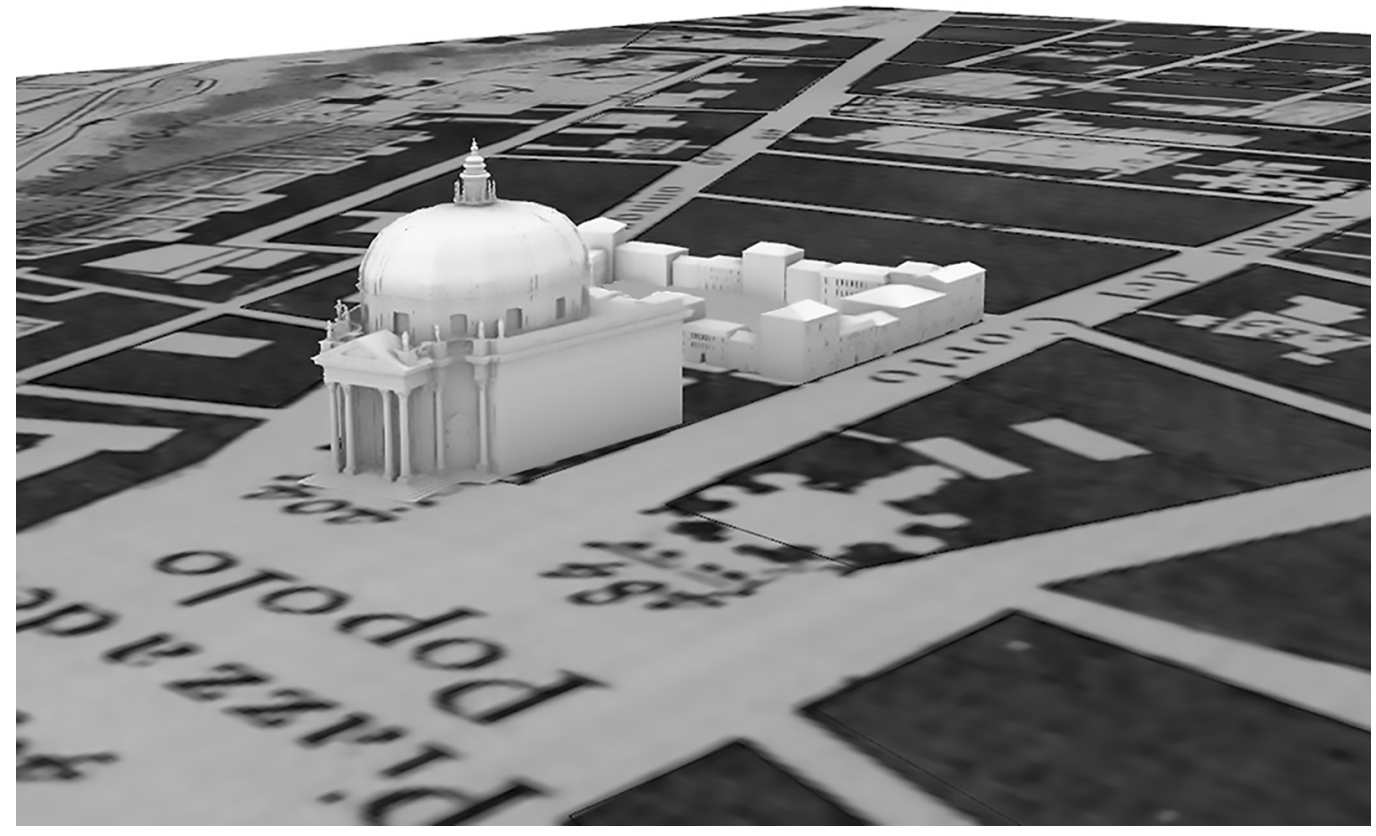




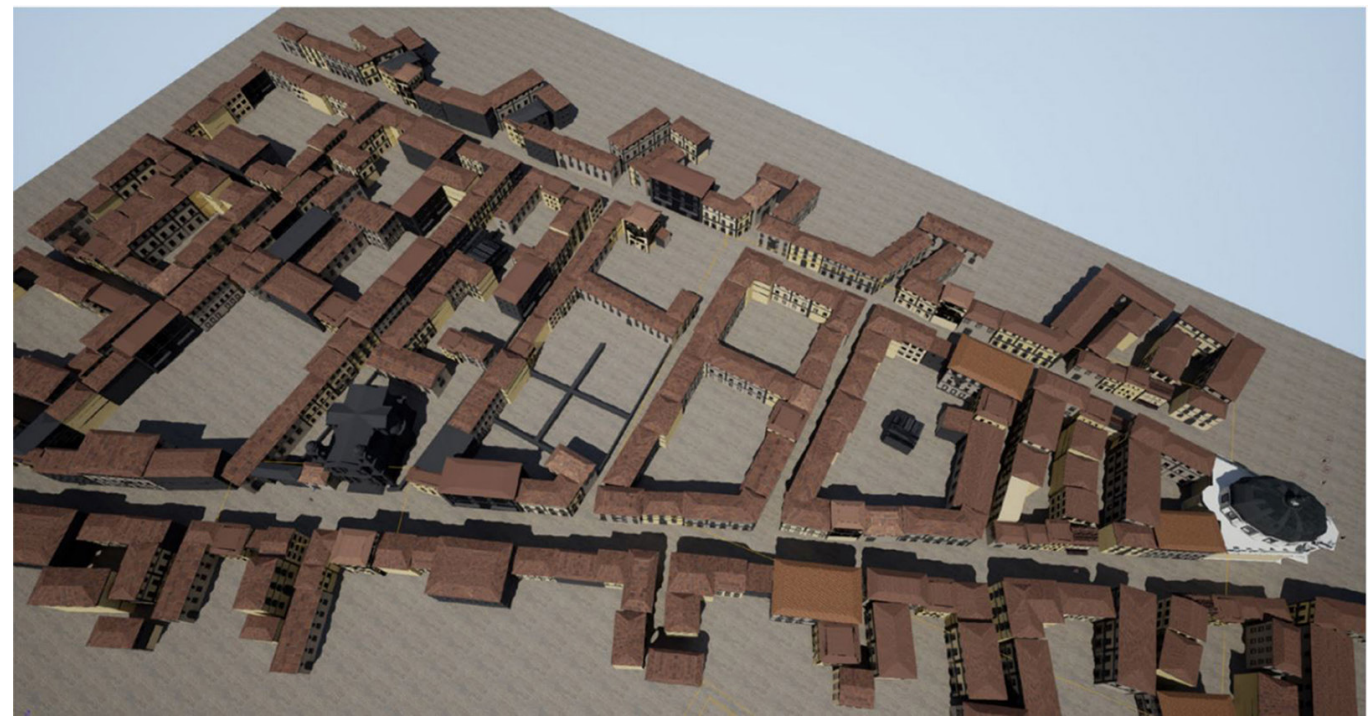

Se per la modellazione degli elementi primari si hanno a disposizione riferimenti iconografici relativi a incisioni, dipinti vedutisti ecc., nella realizzazione degli edifici ed elementi architettonici secondari si procede mediante la realizzazione di un abaco degli elementi architettonici caratteristici dell'epoca (come tipologie di tetti e caminetti, finestre, elementi decorativi ricorrenti, ecc.), che divengono oggetti parametrici, per meglio potersi adattare alle varie tipologie di edifici. Successivamente si individuano i riferimenti metrici, l'impronta degli edifici e le ipotetiche altezze (da I a 3 piani e sottotetto) e si combinano tutti i vari elementi per la costituzione di classi di edifici divisi in diversi modelli (fig. 8). Si effettua quindi uno studio dettagliato delle diverse zone della città, per le quali è possibile definire la percentuale di presenza delle varie classi di edifici. Infine, l'utilizzo di uno specifico software di nome Railclone consente di combinare parametricamente le classi di edifici, seguendo una geometria prestabilita, così da sembrare randomica (fig. 9). Si procede quindi con l'unione di tutte le diverse componenti, per passare alla fase di editing finale e inserire la ricostruzione così conformata all'interno di un software chiamato Unreal Engine, una tra le piattaforme più utilizzate per lo sviluppo di videogiochi e interazioni (figg. I 0, I I), e si sviluppa la narrazione anche tramite la modellazione dei personaggi (fig. 12).

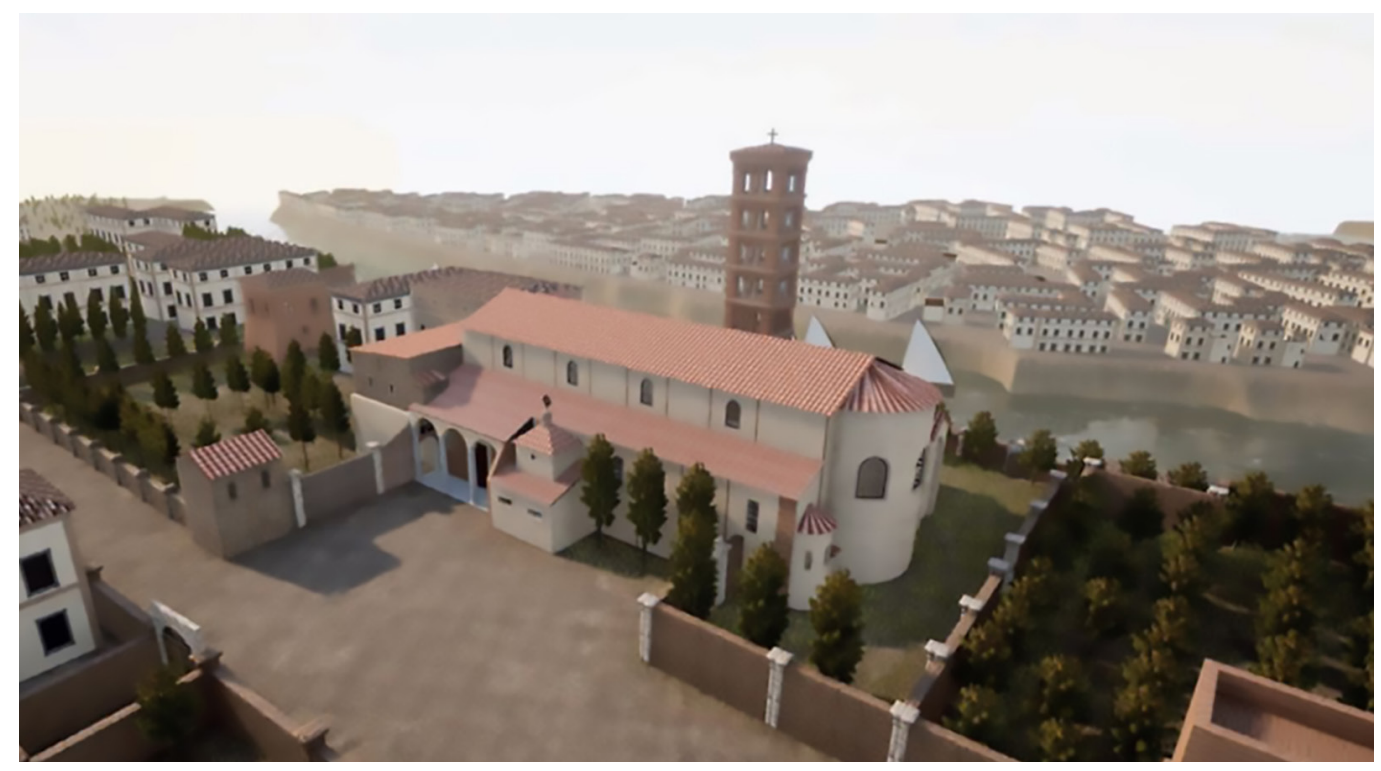




\section{Conclusioni}

Da qualche anno si nota un forte impulso al coinvolgimento delle nuove generazioni nella divulgazione del patrimonio artistico-architettonico. Le ricostruzioni virtuali e i games adempiono a questo compito e si configurano come validi strumenti per la formazione e l'apprendimento. I serious games si presentano come elementi trasversali per la nostra disciplina toccando tematiche di affidabilità delle informazioni da divulgare e delle ricostruzioni tridimensionali, approdando persino a discipline più grafiche, come visual storytelling, branding e identità visiva.

La ricostruzione $3 \mathrm{~d}$ della città di Roma nel 1700 consente output in diverse direzioni, tra cui quello di ricostruire una 'bolla del tempo' di Roma, con la quale, implementando le epoche di ricostruzione, disseminare l'evoluzione storica della città, anche attraverso aneddoti narrativi e curiosità che si discostano dalla storia canonica, mantenendo fede alla scientificità. Da non dimenticare che, in un momento storico in cui lo scambio di messaggi, contenuti e informazioni avviene su di un piano virtuale, un momento in cui la fruizione del patrimonio avviene in uno spazio intangibile, la ricostruzione 3d della Roma del '700 (fruibile in modalità gaming) riesce a valorizzare un aspetto intangibile comunicando un luogo lontano nel tempo e nello spazio.

Fig. 12. Character 3D di Carlo Rainaldi e Gian Lorenzo Bernini.
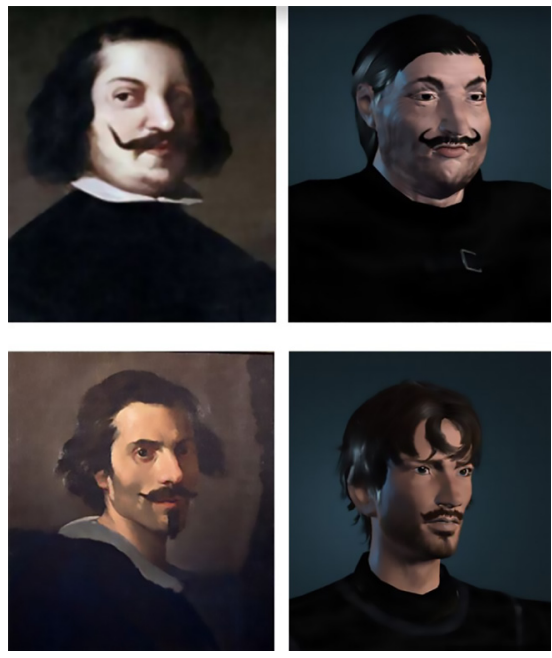

\section{Riferimenti bibliografici}

Antinucci F. (200 I). La scuola si è rotta: Perché cambiano i modi di apprendere. Bari: Editori Laterza.

Antinucci F. (20|4). Comunicare nel museo. Bari: Editori Laterza.

Fanini B. et al. (20I3). Aquae Patavinae VR, dall'acquisizione 3D al progetto di realtà virtuale: una proposta per il museo del termalismo. Padova: Antenor Quaderni - Padova University Press.

Pescarin S. (a cura di). (2020). Videogames, Ricerca, Patrimonio Culturale. Milano: Franco Angeli srl.

Viola F., Idone Cassone V. (2017). L'arte del coinvolgimento. Emozioni e stimoli per cambiare il mondo. Milano: Hoepli.

\section{Autori}

Tommaso Empler, Sapienza Università di Roma, tommaso.empler@uniromal.it

Adriana Caldarone, Sapienza Università di Roma, adriana.caldarone@uniromal.it

Elena D'Angelo, Sapienza Università di Roma, elena.dangelo@uniromal.it

Per citare questo capitolo: EmplerTommaso, Caldarone Adriana, D'Angelo Elena (2021). Una Roma in cui giocare: ricostruzioni 3D e serious games dalla pianta del Nolli/A Rome to play in 3D: reconstructions and serious games from Nolli plant. In Arena A., Arena M., Mediati D., Raffa P. (a cura di). Connettere. Un disegno per annodare e tessere. Linguaggi Distanze Tecnologie. Atti del $42^{\circ}$ Convegno Internazionale dei Docenti delle Discipline della Rappresentazione/Connecting. Drawing for weaving relationship. Languages Distances Technologies. Proceedings of the $42^{\text {th }}$ International Conference of Representation Disciplines Teachers. Milano: FrancoAngeli, pp. 680-699. 


\title{
A Rome to Play in: 3D Reconstructions and Serious Games from Nolli Plant
}

\author{
Tommaso Empler \\ Adriana Caldarone \\ Elena D'Angelo
}

Abstract

This article exposes the reconstruction methods of Rome during the mid-1700s, to create a serious game capable of communicating and disseminating the social and cultural context. The method consists in an accurate sources and data analysis to capture, translate, and synthesize relevant historical components. Starting point consists in the interpretation of place through images. In this way representation acquires a fundamental role and creates a linked to a scenery faithful to reality. Reconstruction process develops according to several steps. Each step plays a fundamental role: definition of orography; construction of cartographic base; composition of urban scene with blocks, streets, alleys and squares; identification of primary, secondary and tertiary components; editing and storytelling. Model's digitization takes place through a discretization process and through information refinement. Goal of serious games is to bring players into a story, involve them in scenarios of the past. Serious games are a support to traditional forms of teaching in schools, they offer high quality educational content.

Keywords

serious games, reliability, Nolli, languages.

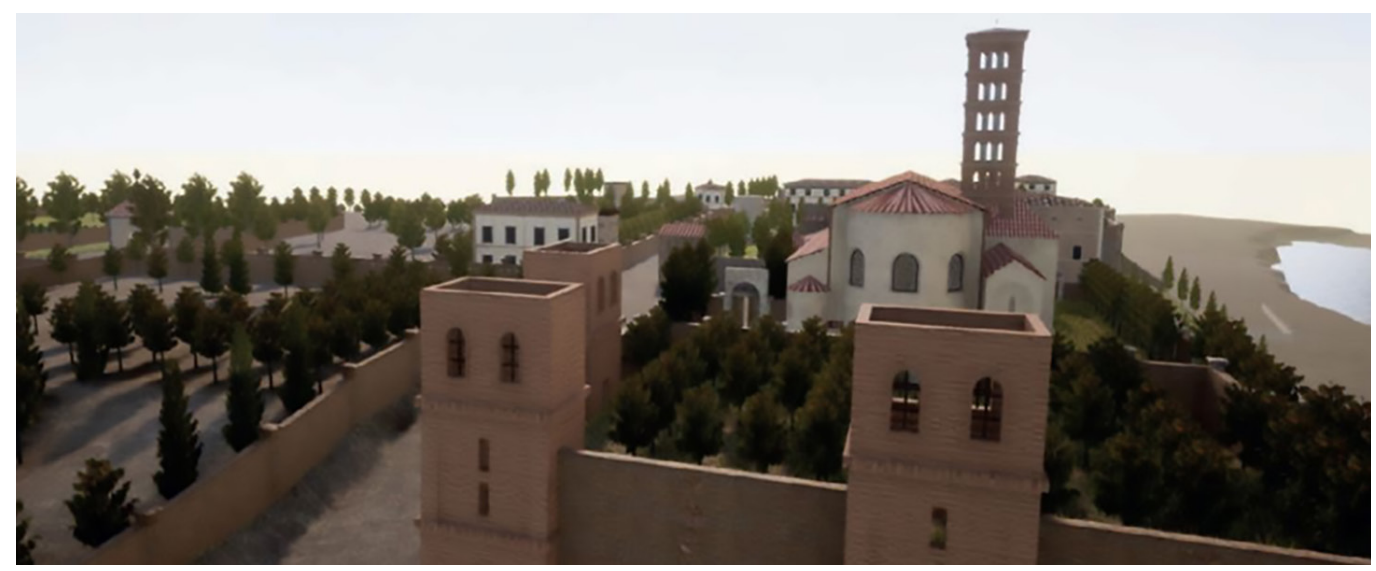




\section{Introduction}

Wide diffusion of cultural phenomenon of video games imposes reflections both in the world of pedagogy (on the role they assume in education), and in disciplinary sector of representation, on the role of communicative languages used for visual representations. The two worlds and concepts are implicitly connected to each other.

Learning methods can be classified into two different classes: symbolic-reconstructive, which allows to learn to decode symbols by reconstructing their meaning in the mind (for example reading and interpretation), perceptive-motor, where someone perceives the context that surrounds him and interacts with it through a continuous exchange of inputs and actions.

Video games exercise both modes at the same time, even in ways that are not allowed in reality [Antinucci 20I4], increasing cognitive abilities.

Serious games are based on these assumptions. According to some scholars, they are used to learn while having fun, having first-person experiences in "history, geography, maths or architecture".

Integrating this tool with traditional forms of teaching in schools of any level, you go beyond the concept of textbook and, at the same time, offer engaging and modular teaching contents according to the knowledge of each student.

Serious games are also aimed at a wider audience and can be considered as the most popular commercial games, where players move in a context and receive truthful and scientific information. Two components play a fundamental role: 3D reconstructions of the scenarios where the player moves and explores; interaction thanks to which a user response corresponds to the game's input. So, users have pseudo real experiences.

In addition to components set out we consider use of narration as a communication strategy for the vehicle of content.

Importance of storytelling in learning has long been known; in fact, storytelling, thanks to emotions it arouses: it generates interpretative processes; it increases involvement and the ability to grasp meanings; it supports critical thinking and problem solving [Viola, Idone Cassone 2017].

Serious games use storytelling that employ images as an expressive medium, better known as Visual Storytelling.

Fig. I. An image of Assassin's creed and 3D reconstruction of Pantheon with a historical fake. Image from. <https:/! areyouserious.altervista org/assassins-creed-puo-essere-conside(accessed 2021, May 25)

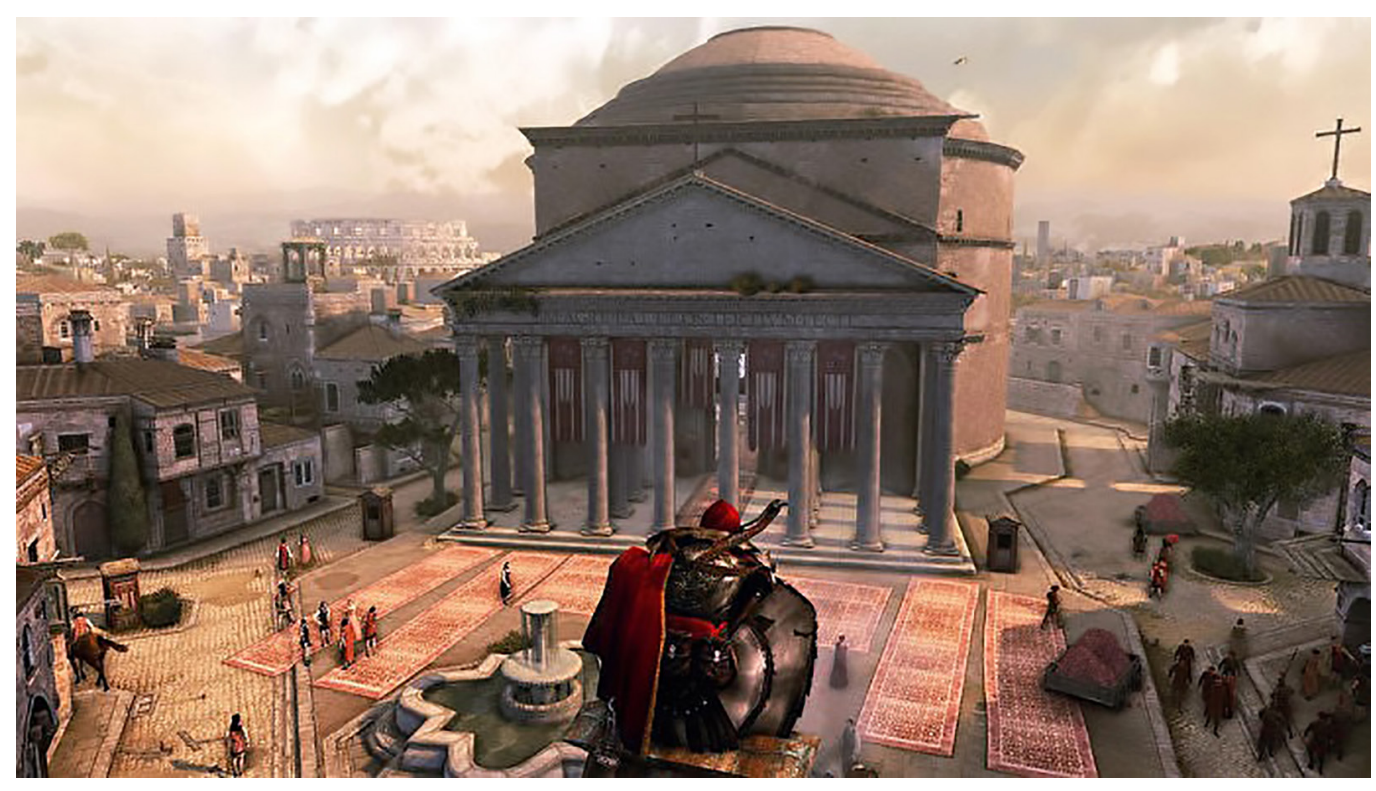


Fig. 2. A chapter of the game of the Trevi distric Aim of the game is to Aim of the game is to reconstruct noble coat of arms, discovering anecdotes about relationship between Rome and some emblematic characters of the family.

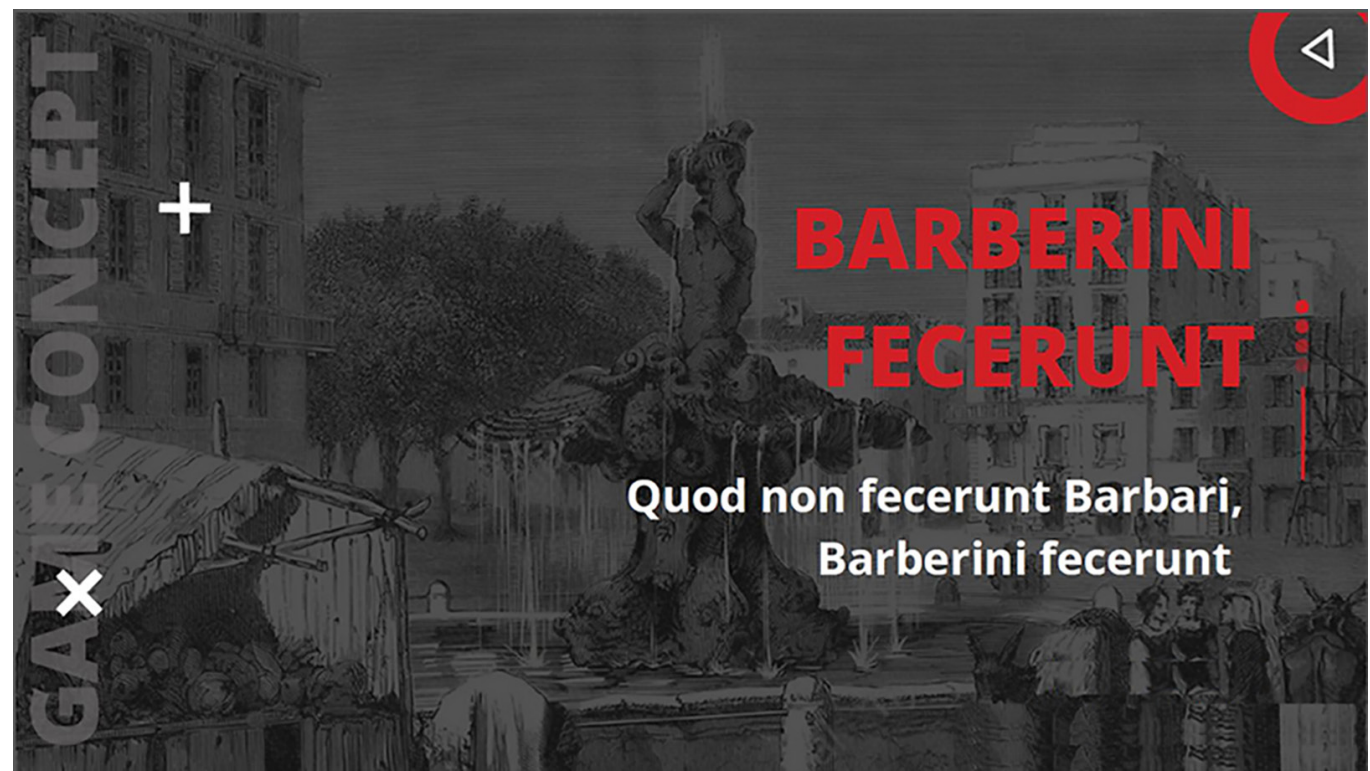

In the field of education and learning, gamification is associated with serious games. This means that videogame techniques are used in non-gaming contexts.

For this reason, gamification helps to involve the public in scientific contexts.

Video games, in fact, help museums to communicate content in a simple and innovative way. Furthermore, they can make the visitor active, and they can make the user an integral part of the experience.
Fig. 3. A chapter of Ripa district game, where the player must help a character find his family between Tiberina island and Jewish ghetto, after plague epidemic that struck Rome between 17 th and 18 th centuries, solving puzzles, courses and mini-games.

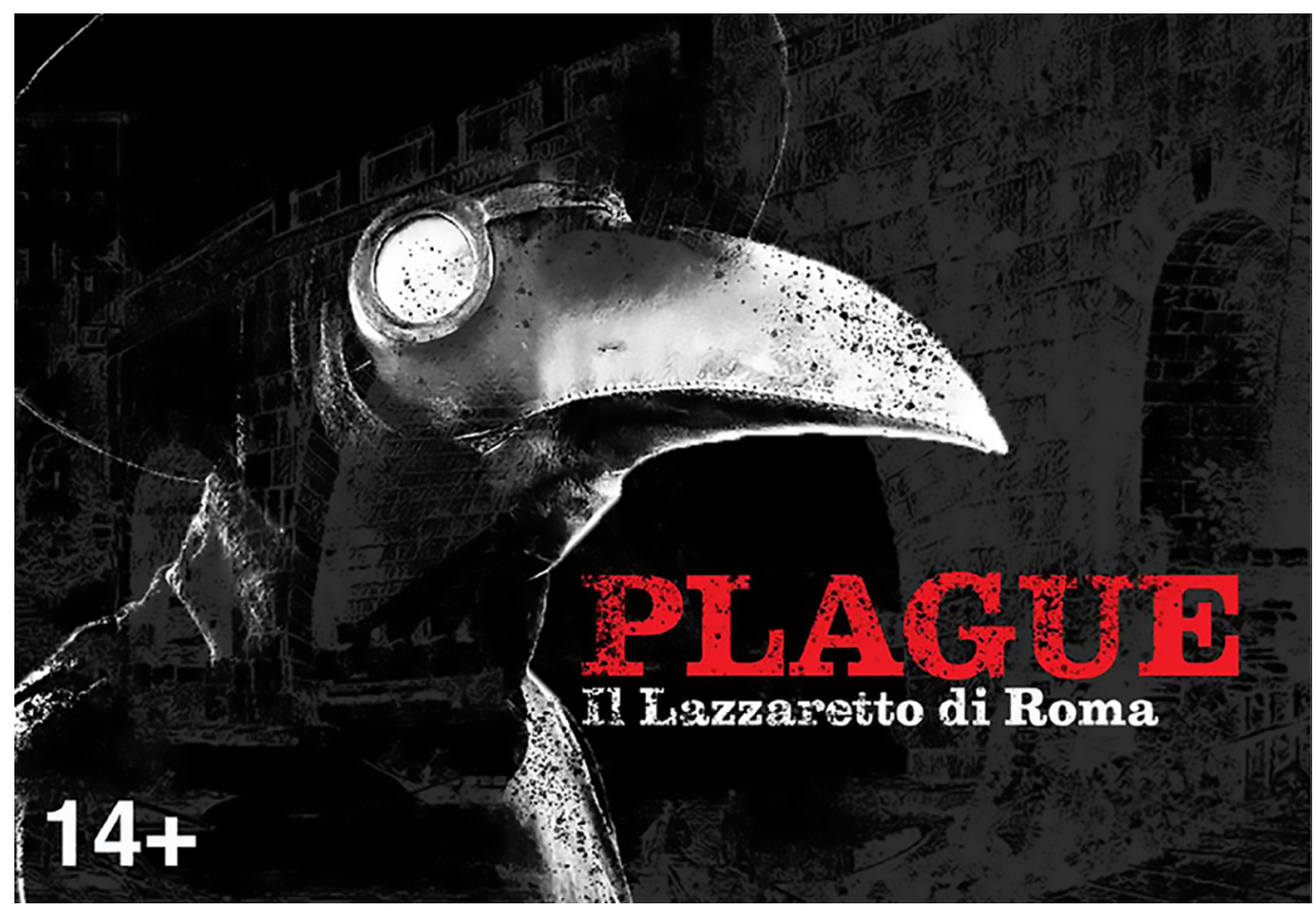


Research sectors that study serious games integrate with each other when they draw up a document called Game Design Document (GDD), where are displayed:

I. Educational goals;

2. Target audience;

3. Commercial, psychological-emotional effects that game arouses in users;

4. Gender and number of players;

5. Storytelling;

6. Scenario;

7. Situation (definition of context and problem to be solved);

8. Game's goals;

9. Characters;

10. Gameplay;

II. Sound and music;

12. User interface and commands;

13. Sponsor and flow of money.

Last, but not least, storyboard is a fundamental component: a graphic table composed of drawings in chronological order, which also identify different game's board and game levels.

Case study focuses on reconstruction of Rome in the mid-1700s. Using Nolli's map of 1748 as a reference, and thus the discipline of representation assumes a primary role linked to three-dimensional scenario and historical-geometric reliability of reconstruction.

Fig. 4. Primary components: Church of Santa Maria in Traspontina in an engraving by Giovan Battista Falda (I) and its 3D model (2); (3) Church of San Giacomo in Piazza Scossacavalli (today Piazza Sant'Andrea della Valle), in an engravin by by Gluseppe Vasi and Di model, (4) Palazzo del Convertendi in an engraving by Pietro Paolo Girelli and 3D model. Modeling G. D'Aniello, R. Favia.
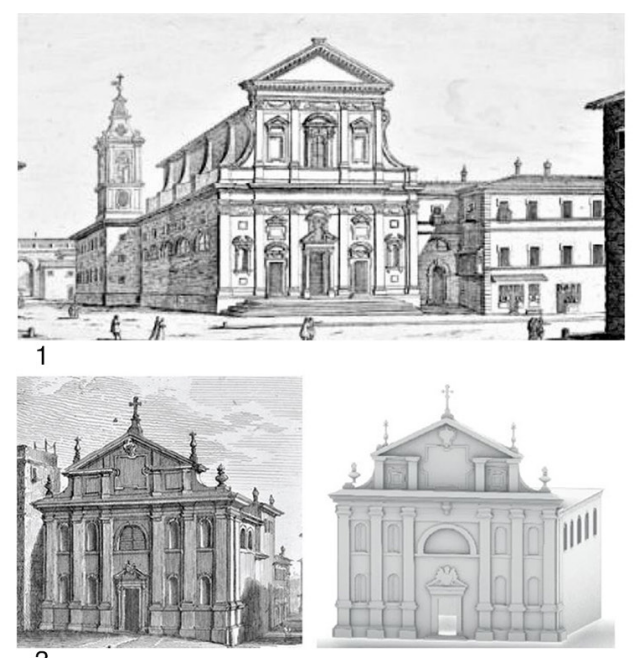
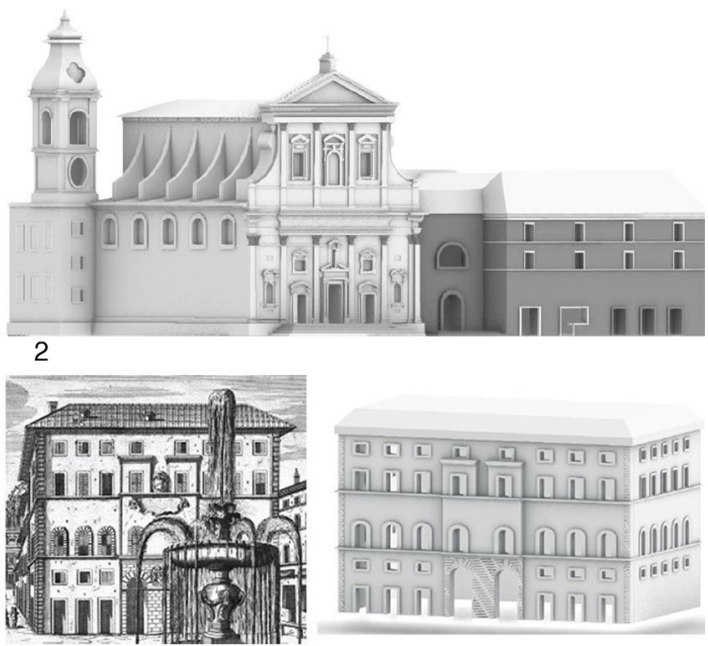

\section{References}

Researches in serious gaming field are applied in different fields: applied research, education, and sector of commercial and recreational videos. In cultural heritage field, we can talk about CNR studies in collaboration with University of Padova and supported by MIUR and Veneto Region. One of the important projects carried out by CNR-ITABC is the "Aquae Patavinae VR project from 3D acquisition to virtual reality: a proposal for terme museum".

It is a virtual reconstruction of inaccessible archaeological sites of thermal Euganean Hills, which can be visited via a real-time platform. During research, archaeological landscape is 
reconstructed using open-source virtual archeology tools. In this way acquired data are understandable both for scientific community and for outside sector's users.

Serious game can also concern field of education. For example, in field of medicine, games are used to prepare surgeons in surgery for unexpected situations. Thus A. Gemelli University Hospital foundation has devised a serious game on some surgical operations in an attempt to reduce the risks due to unforeseen events that could arise during an actual operation.

An example is a training of surgeons in room, with the aim of preparing professionals for unexpected situations. A. Gemelli University Hospital foundation invented a serious game which deals with surgical operations to reduce risks due to unexpected events that could arise during real operation.

XVR platform, on the other hand, allows to create different danger scenarios (fires, road or air accidents, etc.). In this way it helps users to train overcoming emergencies.

There are many specialized companies in serious games aimed to educational use. These applications take advantage of virtual environments to develop operational capabilities within 'unsafe' contexts.

Third application is the commercial games Assassin's Creed Origins Discovery tour and Pacemaker. The first one is a video game by Ubisoft Montreal. It virtually reproduces fake stories set in open world contexts. Player knows the plot by sequence of events. Landscapes recreates contexts that really existed by partially reproducing urban structure of the past (fig. I).

The second one is a video game by Impact Games. The game simulates Israeli-Palestinian war. It is conceived as an instructive serious game that proposes a peaceful resolution of continuous conflicts of those territories. Furthermore, episodes in the game partly actually happened and they tell a relevant story of humanity.

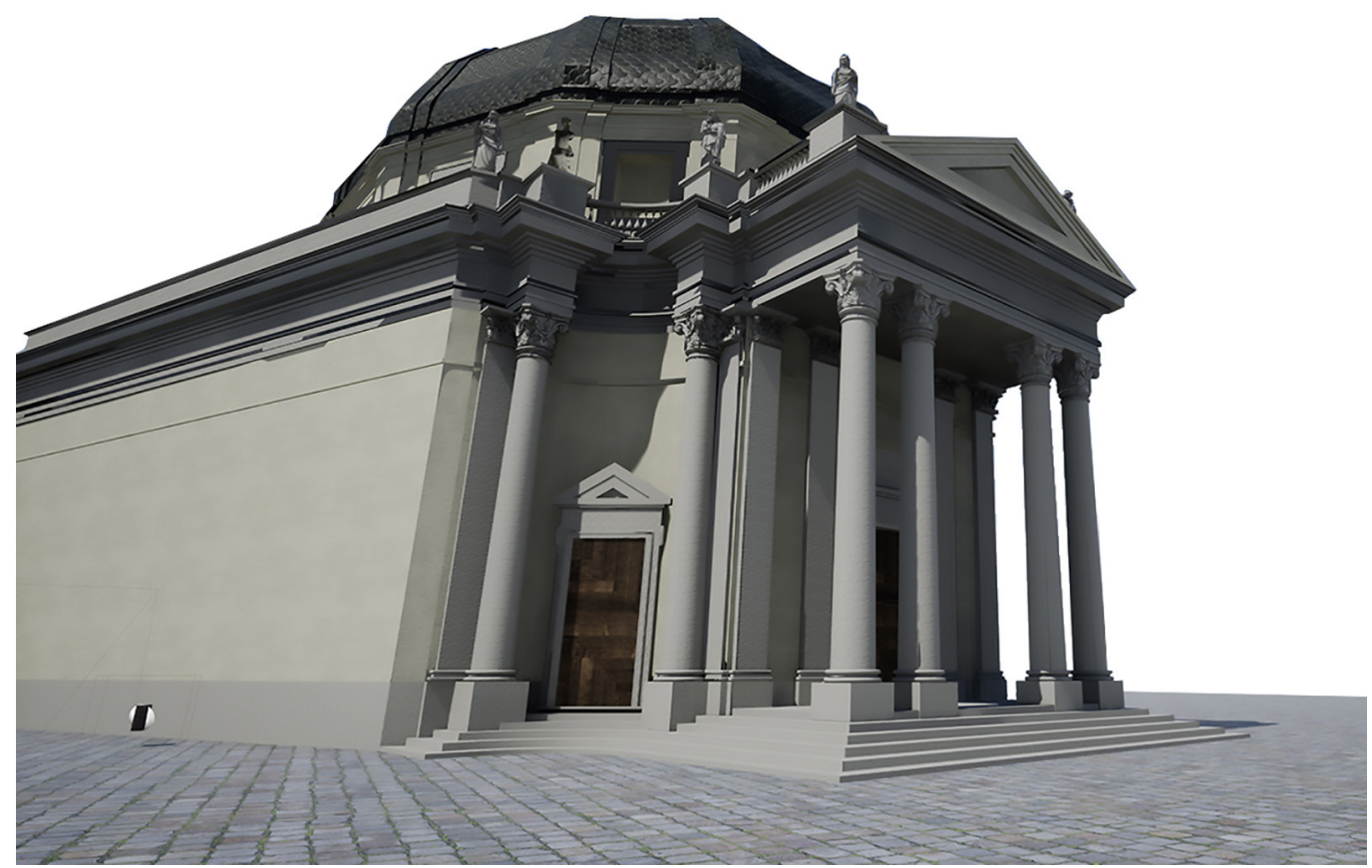


Fig. 6. Construction of a ary building (digital elaboration by F. G. D'intino, E. Kinj)

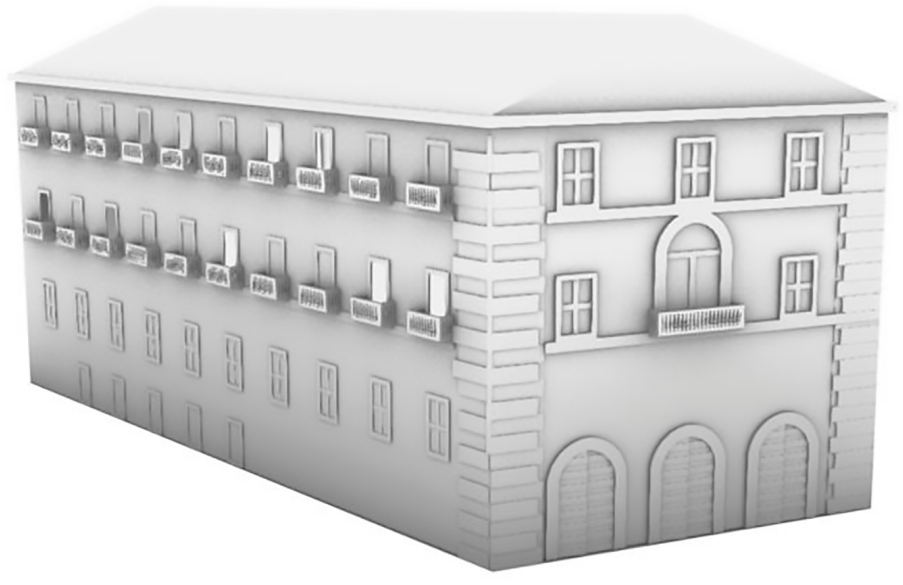

\section{Methodology}

Communication process of reconstructing Rome in the mid-1700s combines narrative creativity (connected to real historical facts) to scientific method. Research focuses on setting, where different disciplines related to representation (such as 3D modeling), history of architecture and architectural survey are mixed in order to work together.Three-dimensional spaces must be characterized by a correct proportion between objects that make up the scene, geometric and historical reliability of elements, and by a recognisability of places.
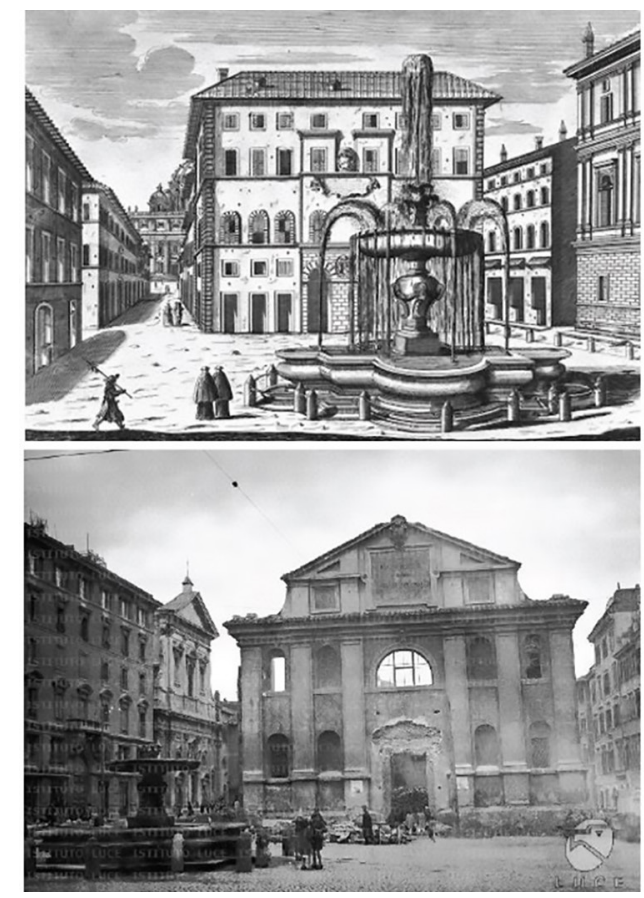
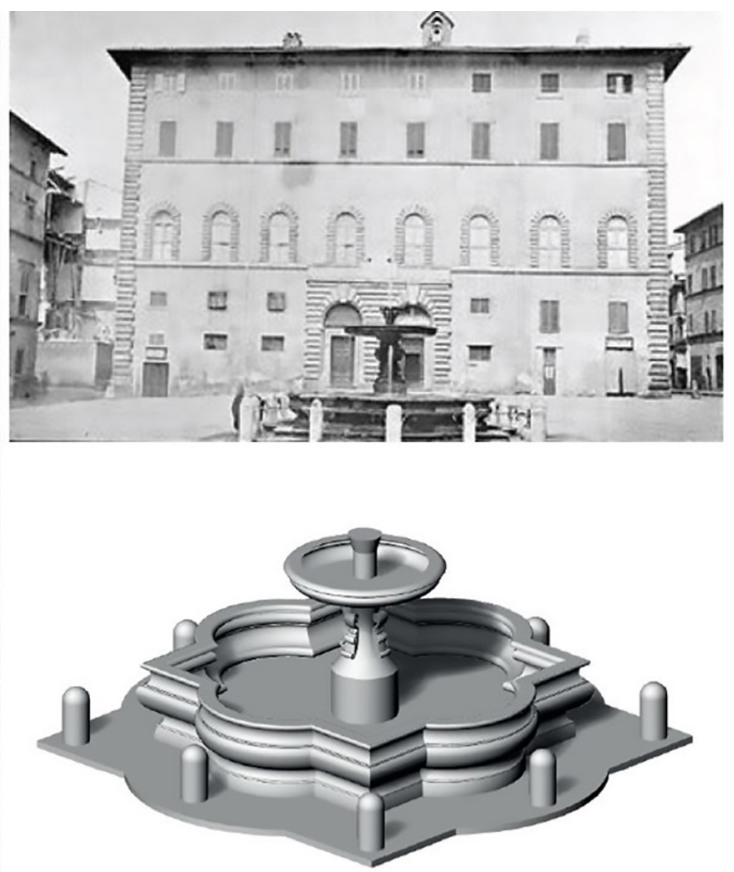

Fig. 7.Tertiary component: 
In the game the city is divided into several districts. Independent plots and goals are created for each ward, in a multi-level setting (figs. 2, 3). In each chapter are defined main characters (used by player) and non-player characters. The game changes according to player's choices.

This method helps connection with the story and allows transmission of information.

Reconstruction of Rome, based on Nolli's 1748 map of Rome, combines direct and indirect data and documentary sources:

- Nolli's map of Rome from 1748;

- Plans of Rome by Greuter of 16 18, by Antonio Tempesta of 1645 and by Giuseppe Vasi of 1781:

- Views of Rome by Giuseppe Falda from 167I, by Giovan Battista Piranesi around 1750, by Giuseppe Vasi from 1754 and by Luigi Rossini from 1822;
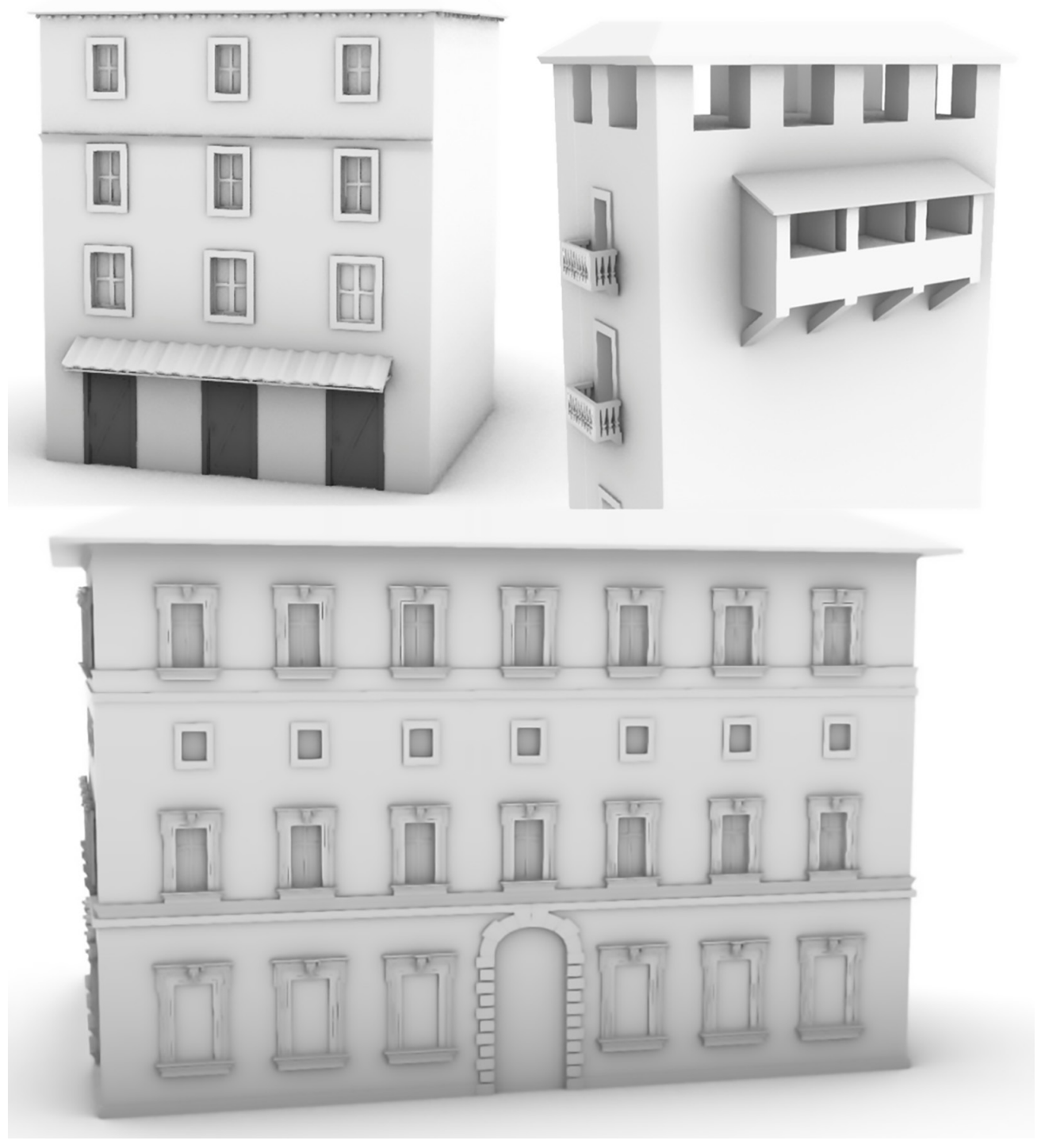
- Buildings and spaces still visible today in their original conformation, detected by sight or with instrumental methods (photogrammetry or terrestrial laser scanner).

Reconstruction process is organized in three basic phases:

- Historical research and data analysis;

Identification and schematization of significant historical and architectural elements;

- Three-dimensional modeling and digitalization through software;

-Verification and editing.

In first phase, orography of the land is reconstructed through historical registers and maps. In second phase, cartographic base of Rome is built starting from the mid-1500s to the mid-1700s, periods of renewal and significant urban growth. Historical maps of Greuter, Tempesta, and Vasi are compared with Nolli's map of Rome to understand evolutionary process of the city.

During the third phase, urban scene is composed to be explored by user. Structure of solids and voids is the first recostruction: it is possible assembling urban layout and defining blocks, streets, alleys and squares.

Subsequently, three categories of elements making up the scene are identified: primary, secondary and tertiary. Primary elements are architectural-urban components emerging within the building, such as squares, churches and noble palaces, iconic and representative objects. Their representation is true and with a high level of detail (figs. 4, 5).

Secondary components are minor building complex (houses, warehouses, laboratories) that makes up the urban morphology, similar throughout the city fabric and belonging to a symbolic category of building (fig. 6).

Finally, tertiary components are objects, mostly decorative, such as fountains, obelisks, sculpture, and artistic elements that describe characteristics of the city center (fig. 7).

An abacus of characteristic architectural elements of the time (such as roofs and fireplaces, windows, recurring decorative elements, etc.) is created in reconstructing secondary buildings, which become parametric objects adaptable to various types of buildings. Subsequently, metric references and hypothetical heights (from I to 3 floors and attic) are identified and collected to be combined to all the various elements to form classes of buildings (fig. 8).

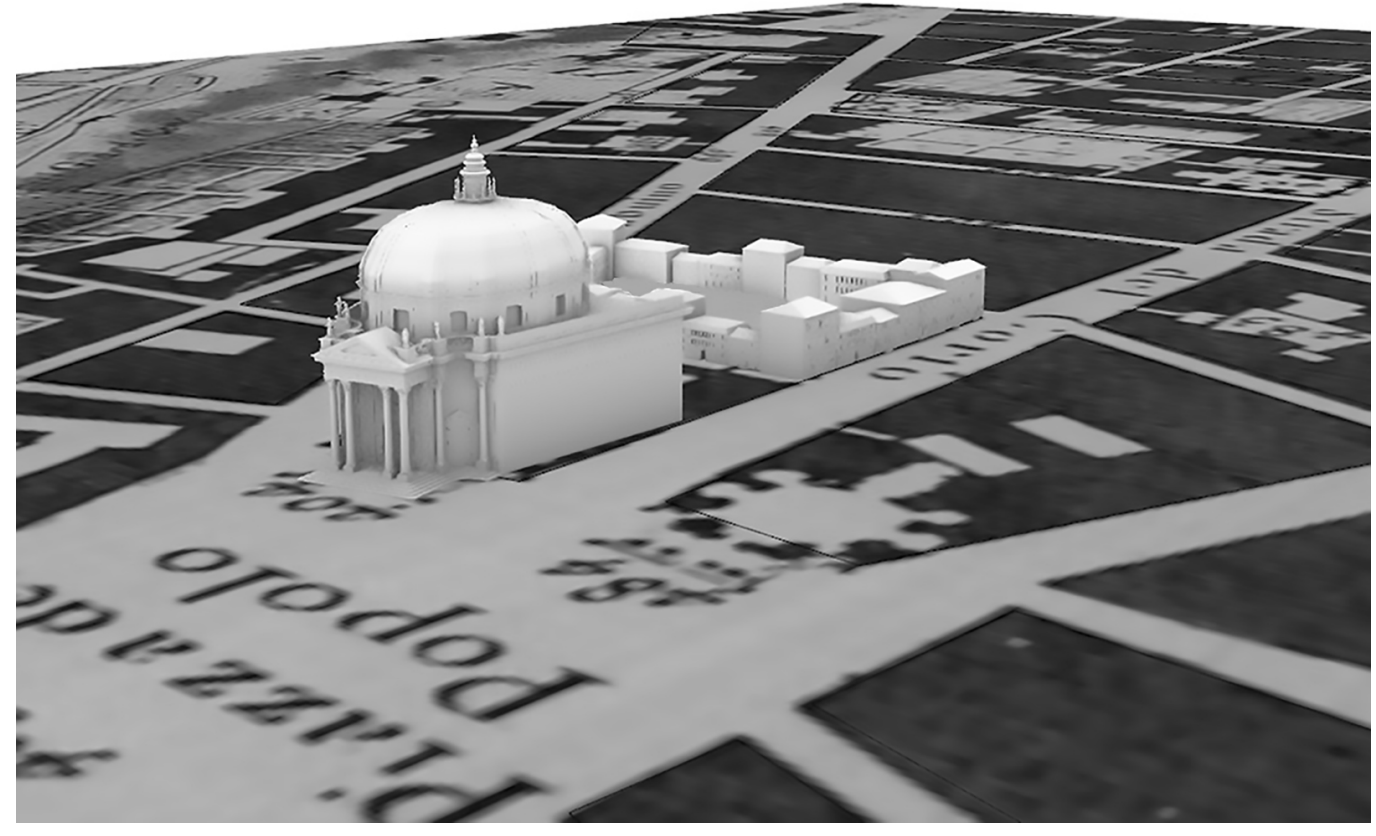




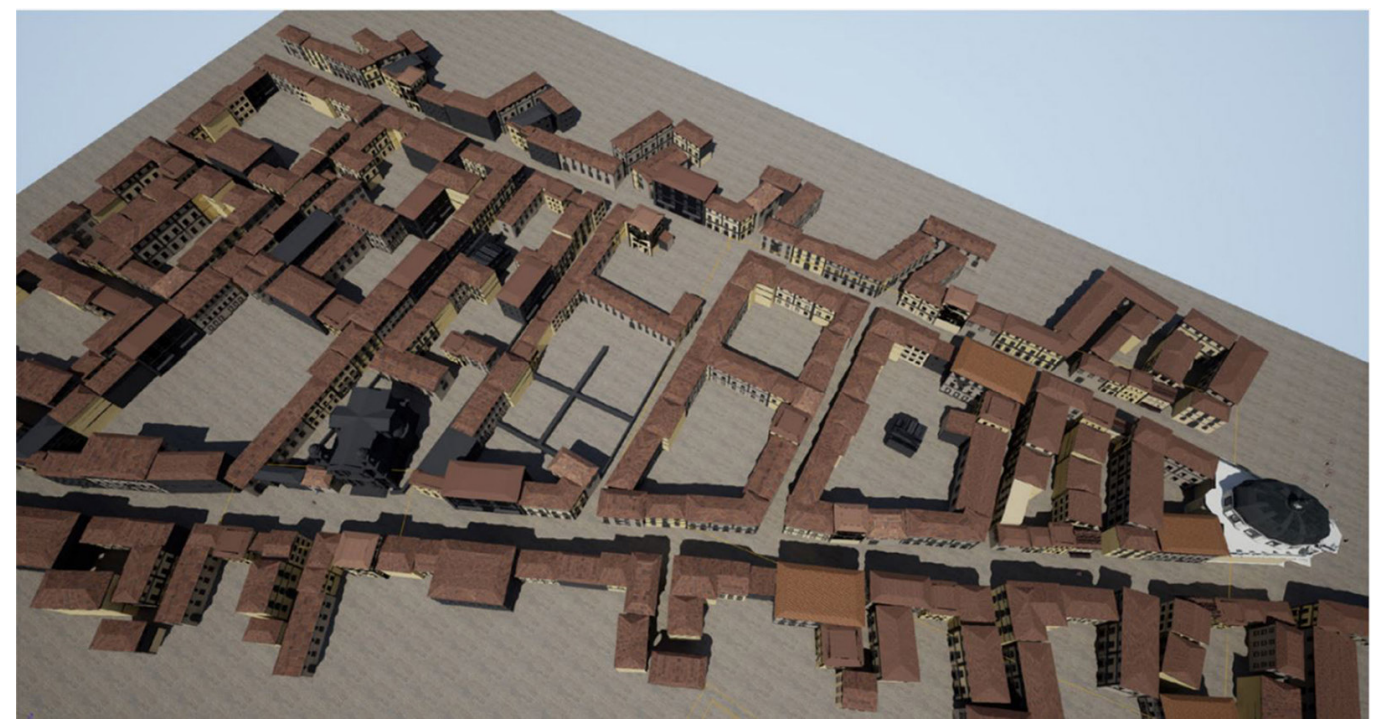

A detailed analysis is then carried out of different areas of the city, divided according to quantity of various classes of buildings they contain. Finally, a software called Railclone allows to parametrically combine classes of buildings, following a predetermined geometry, so as to appear randomly disposed (fig. 9). Then follows an union of all different components, to move on to final editing phase and insert obtained reconstruction into Unreal Engine software, one of the most used platforms for development of videogames and interactions (figs. 10, II). The very last step is characters modeling (fig. 12).

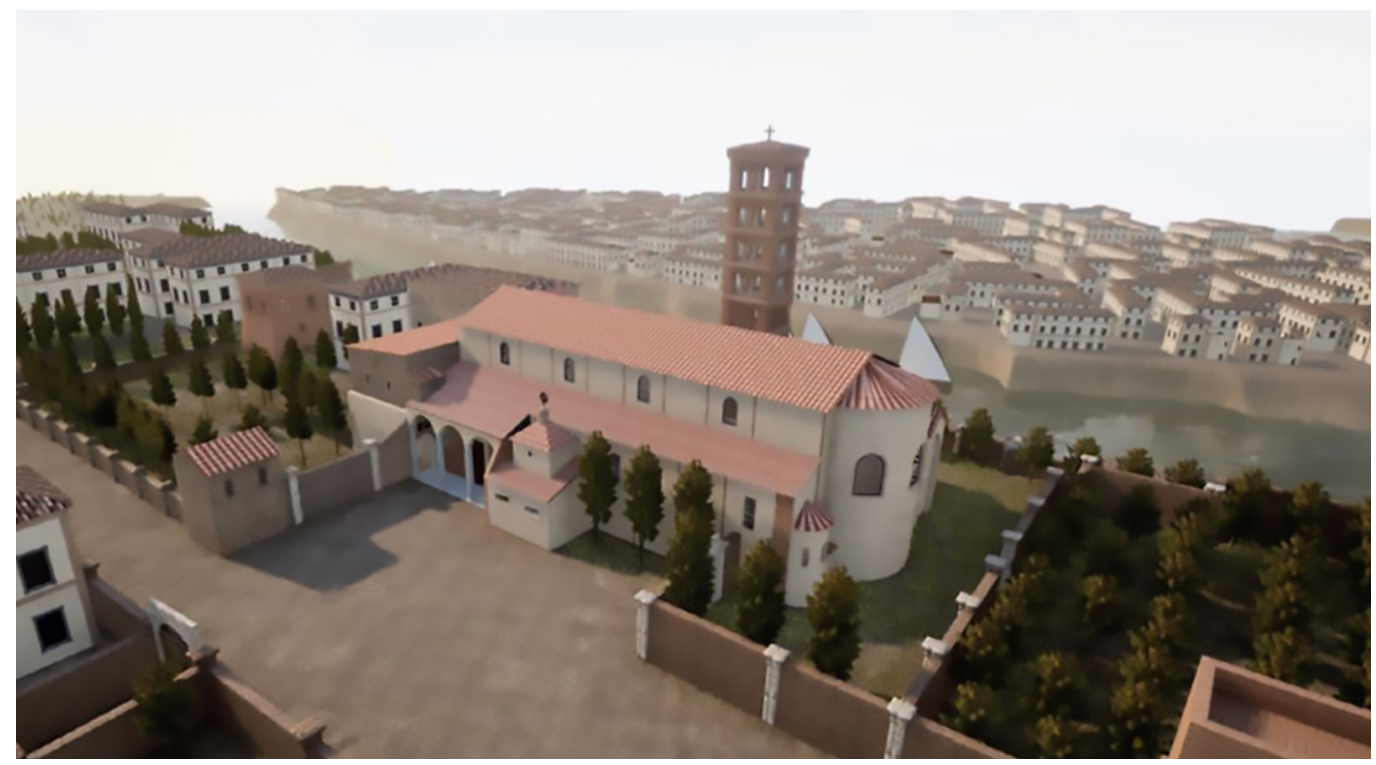




\section{Conclusions}

Since a few years it has been noted that new generation are more involved in dissemination of artistic-architectural heritage. Virtual reconstructions and games are adapted to this function and are transformed into excellent tools for training and learning. Serious games are transversal components: they involve discipline of representation (for reliability of information and three-dimensional reconstructions), graphic disciplines (through visual storytelling, branding and visual identity). Roma 3D reconstruction in 1700 leads to different outputs. For example, it allows to reconstruct a 'time bubble' of Rome. With it, historical evolution of the city can be disseminated through anecdotes and curiosities that move away from canonical history, while keeping faith with scientificity.

At time when exchange of messages, contents and information takes place virtually, 3D reconstruction of Rome in 18th century (usable in gaming mode) is able to enhance an intangible heritage by communicating a distant place in time and space.
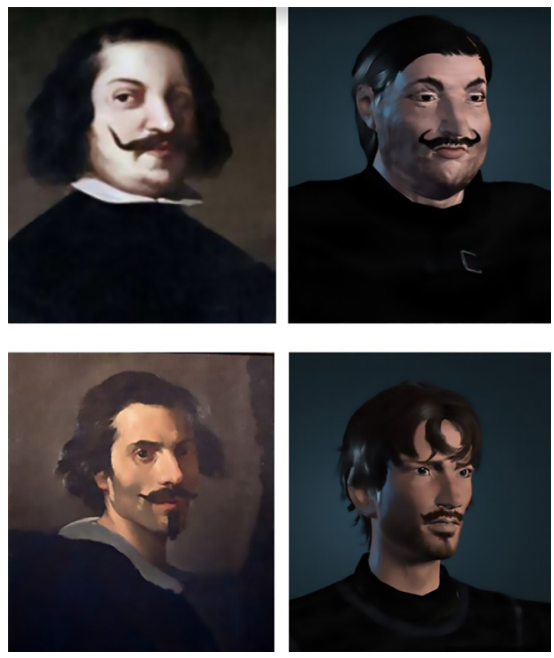

\section{References}

Antinucci F. (200 I). La scuola si è rotta: Perché cambiano i modi di apprendere. Bari: Editori Laterza.

Antinucci F. (20|4). Comunicare nel museo. Bari: Editori Laterza.

Fanini B. et al. (20I3). Aquae Patavinae VR, dall'acquisizione 3D al progetto di realtà virtuale: una proposta per il museo del termalismo. Padova: Antenor Quaderni - Padova University Press.

Pescarin S. (a cura di). (2020). Videogames, Ricerca, Patrimonio Culturale. Milano: Franco Angeli srl.

Viola F., Idone Cassone V. (2017). L'arte del coinvolgimento. Emozioni e stimoli per cambiare il mondo. Milano: Hoepli.

\section{Authors}

Tommaso Empler, Sapienza Università di Roma, tommaso.empler@uniromal.it

Adriana Caldarone, Sapienza Università di Roma, adriana.caldarone@uniromal.it

Elena D'Angelo, Sapienza Università di Roma, elena.dangelo@uniroma l.it

To cite this chapter. EmplerTommaso, Caldarone Adriana, D'Angelo Elena (2021). Una Roma in cui giocare: ricostruzioni 3D e serious games dalla pianta del Nolli/A Rome to play in 3D: reconstructions and serious games from Nolli plant. In Arena A., Arena M., Mediati D., Raffa P. (a cura di). Connettere. Un disegno per annodare e tessere. Linguaggi Distanze Tecnologie. Atti del $42^{\circ}$ Convegno Internazionale dei Docenti delle Discipline della Rappresentazione/Connecting. Drawing for weaving relationship. Languages Distances Technologies. Proceedings of the $42^{\text {th }}$ International Conference of Representation Disciplines Teachers. Milano: FrancoAngeli, pp. 680-699. 